\title{
THE IMPACT OF MICROBIAL METABOLISM ON MARINE DisSOLVED ORGANIC MATTER
}

\author{
Elizabeth B. Kujawinski \\ Department of Marine Chemistry and Geochemistry, Woods Hole Oceanographic \\ Institution, Woods Hole, Massachusetts 02543; email: ekujawinski@whoi.edu
}

\begin{abstract}
Microbes mediate global biogeochemical cycles through their metabolism, and all metabolic processes begin with the interaction between the microbial cell wall or membrane and the external environment. For all heterotrophs and many autotrophs, critical growth substrates and factors are present within the dilute and heterogeneous mixture of compounds that constitutes dissolved organic matter (DOM). In short, the microbe-molecule interaction is one of the fundamental reactions within the global carbon cycle. Here, I summarize recent findings from studies that examine DOM--microbe interactions from either the DOM perspective (organic geochemistry) or the microbe perspective (microbial ecology). Gaps in our knowledge are highlighted and future integrative research directions are proposed.
\end{abstract}

Key Words dissolved organic matter, microorganisms, metabolomics, ABC transporters

\section{OVERVIEW}

When you walk into a biologist's (or biochemist's) office, you will likely see a large poster of all the chemical reactions that occur in a cell's metabolism. Perhaps, like me, you will be struck by the sheer complexity of the pathways, the interdependence of all the reaction arrows, and the critical role played by each reaction in the life of the cell. Now imagine a reaction map for a "superorganism" such as the ocean. Instead of individual compounds connected by reaction pathways, the map would show organisms connected by chemical compounds that pass through the dissolved organic matter (DOM) pool. Averaged over large spatial and temporal scales, these individual organisms and chemical interactions would culminate in the observed global elemental cycles. This view of the marine ecosystem is ascending in the microbial ecology literature (Azam \& Worden 2004, Gasol et al. 2008, Raes \& Bork 2008), and the notions of ecological functioning units and synergistic 
chemical interactions are supported by field and laboratory data (Grossart \& Simon 2007, Hofle et al. 2008, Morris et al. 2008, Paul et al. 2009, Sinsabaugh \& Findlay 2003, Teira et al. 2008). Nonetheless, this view will remain incomplete if we focus on descriptions of only the microbes in the oceans. To complete the map, we must also identify the compounds that serve as the currency for these interactions, i.e., those that are traded between organisms for nutrition (Lau \& Armbrust 2006) or communication (Gram et al. 2002) as well as those that are exuded as waste or in chemical defense (Wichard et al. 2008). Integration of chemical composition assessments with microbiological analyses would provide novel, holistic views on the interactions and processes that govern microbial metabolism in the ocean (Figure 1). In sum, this research approach would realize the vision of ecosystem biology as proposed by Azam \& Worden (2004) and Raes \& Bork (2008).

To achieve this goal, we must examine the molecular-level composition and dynamics of reactive DOM as it pertains to different organisms and growth conditions. Microbial assimilation of small DOM molecules $(<600 \mathrm{Da})$ is determined by a suite of microbial transport proteins, expressed by microbial consortia. To date, the substrate specificity of these transporters is poorly constrained, but in general, they are presumed to bind to lowmolecular-weight (LMW) biological monomers such as amino acids and sugars. In contrast, most compositional studies of DOM have focused on the high-molecular-weight (HMW) fraction $(>1000 \mathrm{Da})$, which is unavailable to these transporters. Thus, historical measurements of DOM and its composition are at odds with our understanding of microbial physiology and DOM uptake.

Ultrahigh-resolution mass spectrometry is one technique that could shed light on the fraction of DOM that is traded among organisms. In particular, electrospray ionization (ESI) coupled to ultrahigh-resolution mass spectrometers selectively detects small (<2000 Da), polar molecules in marine DOM. For efficient analysis and interpretation, these data need to be combined with lists of metabolites predicted from genome sequences of single species and complex communities. However, biogeochemists and microbial ecologists rarely coanalyze samples, and these two scientific fields are developing fairly independently. Yet the questions and intellectual approaches within these communities are very similar. Both are interested in describing the diversity of their mixtures (DOM and microbial consortia) and in characterizing the functional role(s) of individual members. Thus, experimental 
designs and statistical tools should be comparable between the two fields and should lend themselves to novel interdisciplinary research themes. The intent of this review is to present interesting and useful perspectives that bridge organic geochemistry and microbial ecology, thus providing a platform for the development of new integrative paradigms for the marine carbon cycle.

\section{WHAT IS DISSOLVED ORGANIC MATTER?}

DOM is the collection of compounds that contain reduced carbon, often bound to heteroatoms such as oxygen, nitrogen, phosphorus, and sulfur. Thus this pool contains dissolved organic nitrogen (DON), dissolved organic phosphorus (DOP), and dissolved organic sulfur (DOS). Given the heterogeneous composition of DOM, it is not surprising that comprehensive compositional analysis has been elusive, and that analytical challenges for DOM characterization remain. Nonetheless, this pool provides the growth substrates and growth factors required for metabolism in free-living microbes, and thus its compositional variability over space and time is a critical factor in elucidating the DOM--microbe interactions at the base of the marine carbon cycle.

Numerous advances have been made recently in techniques for the extraction of DOM (Dittmar et al. 2008, Kim et al. 2003, Koprivnjak et al. 2009) and comprehensive reviews have been published on techniques used for DOM characterization in marine and freshwater environments (Benner 2002, Mopper et al. 2007). These techniques range from bulk concentrations to molecule-specific analyses, often with a concomitant increase in time and effort required for analysis (Dittmar \& Paeng 2009). For example, many of our insights into the global carbon cycle stem from bulk dissolved organic carbon (DOC) and DON measurements that have become fairly routine in oceanographic laboratories. Although these results can be used in numerical models to infer large-scale global transport processes (Hopkinson \& Vallino 2005), bulk analyses mask finer-scale changes that may be important for microbial diversity and metabolic function. As a result, numerous investigators have developed and utilized methods that provide more information on selected compounds or compound classes. These techniques can be divided into two categories: (a) those that rely on chemical or physical fragmentation processes to break large macromolecules into small pieces and $(b)$ those that do not fragment but detect individual molecules or compound 
classes. These techniques are often complementary and can be used together to characterize a suite of DOM compounds.

In the first category, we find techniques that focus on the analysis of polymers that are easily hydrolysed to monomers such as amino acids, sugars, and lignin phenols. These methods start with a fragmentation step such as acid-based hydrolysis, and the resulting monomers are analyzed (and often quantified) with chromatography and/or mass spectrometry. In principle, there is no size limit to these techniques because the target fragmentation step is based on the presence or absence of the appropriate chemical linkage. In practice, some large molecules are resistant to full hydrolysis due to steric hindrance or covalent cross-linking. These techniques have proved extremely useful as many of the monomers or small molecules have known biological function and their dynamics can be interpreted within existing metabolic models. The only caveat to these techniques has been that the original molecule cannot be reconstructed from the monomer data and that DOM is more resistant to hydrolysis with age (Lee et al. 2004). Thus, these methods are useful shortly after biological production but are difficult to use effectively as DOM ages. They can be applied to bulk seawater as well as to HMW material that has been extracted and dried. A detailed review of these techniques and their caveats are presented in Kirchman (2003).

In the second category, we find techniques that analyze intact molecules through either mass spectrometry or nuclear magnetic resonance (NMR) spectroscopy (as reviewed in Mopper et al 2007). Because there is no fragmentation step, the mass spectral analyses are often limited to small molecules, with the size cut-off depending on the instrument used. Target molecules are extracted from seawater, purified (if necessary or possible), ionized, and characterized with a mass spectrometer (Figure 2). For example, the same analytical methods that quantify hydrolysis products described above can be used to quantify free, or dissolved, biological monomers like amino acids. For structural characterization of unknown DOM components, tandem mass spectrometry (MS/MS) is often used. Coupled with ESI, mass spectrometry has great promise for applications in DOM characterization because ESI ionizes intact compounds that are ionic at analysis $\mathrm{pH}$ (alkaline for negativelycharged ions and acidic for positively-charged ions), and it can be used with liquid chromatography preseparation. Thus ESI MS can provide fingerprint analyses for polar, 
low- to moderate-molecular-weight compounds within complex mixtures such as marine DOM.

This approach can be used to examine temporal and spatial dynamics of known DOM constituents as well as to elucidate the composition of unknown DOM components. For example, molecular-level characterization of polar DOM is achieved when ultrahigh resolution mass spectrometers such as the Fourier transform ion cyclotron resonance mass spectrometer (FT-ICR MS) are used. The FT-ICR MS provides baseline resolution for tens of peaks per nominal mass, culminating in thousands of peaks over the detected mass range of $50<\mathrm{m} / \mathrm{z}<2000$. Results of ESI FT-ICR MS studies have been generally consistent with bulk-level or proxy measurements for such processes as photochemical degradation (Kujawinski et al. 2004, Sleighter \& Hatcher 2008) or microbial DOM production (Kujawinski et al. 2009). Although most compositional studies using ESI FT-ICR MS have focused on broad environmental distributions, interesting insights have been gained from those that incorporate a focus on microbial impacts on DOM composition (Kujawinski et al. 2009, Rossello-Mora et al. 2008).

\section{CURRENT UNDERSTANDING OF DOM--MICROBE INTERACTIONS}

Microorganisms have four possible interactions with individual molecules in DOM. First, they can ignore the molecule, i.e., the DOM is refractory vis-à-vis their metabolism. Much of marine DOM is indeed impervious to short-term microbial alteration as a result of abiotic and biotic rearrangement or polymerization reactions. Second and third, cells can assimilate an entire molecule (i.e., consumption) or a fragment cleaved by an extracellular enzyme (i.e., modification). In both of these cases, monomers such as amino acids or sugars are incorporated into metabolic pathways for biomass synthesis or energy production. Lastly, cells can release an organic molecule that becomes part of DOM, i.e., production. This release is controlled and modulated by numerous processes within cells and consortia. In short, the composition of DOM and the metabolic capabilities of the resident microbes are clearly interdependent in controlling the overall organic carbon cycling in the marine environment. However, this interdependence is difficult to examine experimentally, and so our understanding of these processes is fragmented, i.e., based on focused studies in disparate fields. Due to space constraints, I have focused this review on water-column 
processes, but microbe-molecule interactions are also critical for particle-associated carbon cycling and readers should consult recently-published reviews on this topic (Arístegui et al. 2009, Azam \& Malfatti 2007, Buesseler \& Boyd 2009).

\section{PRODUCTION OF DOM}

Cellular material is released by metabolically active microbes, according to nutrient status, growth conditions, and the presence of other microbes (see review in Carlson 2002). In addition, microbes may release compounds for nutrient acquisition (e.g., metal-binding ligands for metal acquisition; Ito \& Butler 2005), for communication (e.g., acyl homoserine lactones for quorum sensing; Gram et al. 2002), or for chemical defense (e.g., polyunsaturated aldehydes for grazing inhibition; Wichard et al. 2008). Lastly, DOM may be released when cells die through processes such as viral lysis, predation by protozoa or bacteria, and senescence (see reviews by Nagata 2000, 2008). The relative contribution of primary production and mortality-related processes to overall DOM production appears to vary as a function of the nutrient status of the environment: Productive, nutrient-rich regions have significant DOM production directly from photosynthesis (consistent with Marañón et al. 2004), whereas oligotrophic, nutrient-poor regions have significant DOM production from grazing processes (Nagata 2000). This overall trend has been attributed to the complexity of the microbial food web in each regime, whereby classic food webs exist in productive regions and highly complex microbial loops exist in oligotrophic regions (Teira et al. 2001). Table 1 is a synthesis of recent literature on DOM production by microbes and microbial consortia.

\section{PHYTOPLANKTON AND PHOTOSYNTHETIC BACTERIA}

The fraction and composition of photosynthetic production released as DOM are highly variable among species and among growth conditions ( $\sim 5--50 \%$; review in Carlson 2002). For example, the variability of HMW carbohydrate exudation by diatoms has been examined in different species (Bertilsson \& Jones 2003), under different growth conditions (Wetz \& Wheeler 2007), and in different nutrient states (van Oijen et al. 2005). These polysaccharides are degraded by heterotrophic bacteria, and the remaining material is 
similar to the acyl polysaccharides observed as the dominant component of HMW DOM (Aluwihare \& Repeta 1999). However, since most diatom exudate is LMW (<1000 Da), much work remains to constrain its composition (Bertilsson \& Jones 2003).

Using monomer analyses, Granum et al. (2002) showed that a large fraction (up to 20\%) may be composed of monosaccharides and amino acids. Using liquid-chromatography/MS, Barofsky et al (2009) have begun to explore the temporal and compositional dynamics of DOM exuded by two diatoms, Skeletonema marinoi and Thalassiosira pseudonana, over different growth stages. Barofsky and colleagues detected hundreds of individual retention time-- $m / z$ pairs that varied across their experiments, suggesting that exudate composition is much more dynamic than previously assumed. Some of these compounds appear to influence the copepod grazing of these diatoms (Barofsky et al. 2010). Interestingly, cocultured diatoms exuded different metabolites than those cultured separately (Paul et al. 2009). These results are consistent with previous work showing that diatoms exude unique DOM profiles when cocultured with bacteria (Grossart \& Simon 2007).

Comparatively little work has been done on the composition of DOM exuded by other autotrophic microbes. Bulk assessments have shown that DOM is indeed exuded by the numerically dominant cyanobacteria Synechococcus and Prochlorococcus (Carlson 2002), but we know little about its composition, although metal-acquisition ligands have been identified and characterized (Ito \& Butler 2005). Nitrogen-fixing cyanobacteria such as Crocosphaera watsonii can exude large quantities of extracellular polysaccharides (Webb et al. 2009), and the colony-forming Trichodesmium erythraeum appears to produce phosphonates (i.e., organic phosphorus compounds with a C--P bond) (Dyhrman et al. 2009).

\section{HETEROTROPHIC BACTERIA}

The composition of DOM produced by bacteria is almost unknown, probably because these organisms are thought to be more important in DOM consumption than in DOM production. However, bacteria produce organic compounds for many of the same reasons as phytoplankton ( 1--10\% released as DOM; review in Carlson 2002). Siderophore production has been documented as a strategy for trace metal acquisition, and acyl homoserine lactones have been observed during bacterial quorum sensing. Much attention 
has been paid, as well, to the production of secondary metabolites, especially those with possible pharmaceutical applications. However, little information is available about the full suite of compounds produced by heterotrophic bacteria under different growth conditions or stages. A notable exception is Gruber et al. (2006), who examined the metabolites produced by a freshwater proteobacterium (Pseudomonas chlororaphis) when grown on glucose. The authors noted that a small fraction of DOM was refractory throughout the 36-day experiment, consistent with the results of Ogawa et al. (2001). The more labile DOM compounds produced by the bacteria were remineralized in the presence of Uronema, a scuticociliate that grazed the bacteria to threshold levels (Gruber et al. 2006). Using ESI FTICR MS, Rossello-Mora et al. (2008) examined internal (and external) metabolite profiles of Salinibacter ruber isolates and showed that different geographical origins of the isolates could be distinguished from their cellular metabolic profiles. Similarly, Kujawinski et al. (2009) showed that DOM molecules present in laboratory cultures of Candidatus Pelagibacter ubique were also detected in open ocean DOM, highlighting the potential role of this organism in marine carbon cycling.

\section{MORTALITY: GRAZING AND LYSIS}

The single-species studies described above are critically important to gauging DOM production under controlled laboratory conditions, but they are limited in environmental relevance to bloom events or other unique circumstances. In complex consortia, predation short-circuits DOM production by individual phytoplankton and/or bacteria. Instead, through lysis, the DOM production processes necessarily change, and so the consumption (and quantity) of DOM are altered as well. Protozoan grazing processes have been the best studied, from bulk DOM dynamics (Caron et al. 1985) to molecular-level assessments (monomers; Nagata \& Kirchman 1992)(ESI MS; Gruber et al. 2006, Kujawinski et al. 2004). On a bulk level, protozoa exert a significant influence on carbon dynamics, and as a result, their grazing has been proposed as the dominant DOM production mechanism in the oligotrophic ocean (Nagata 2000). Grazing also has an impact on DOM composition (Gruber et al. 2006, Kujawinski et al. 2004) and can release both labile and refractory compounds (Nagata \& Kirchman 1992). Comparatively little work has been conducted on viral lysis as a DOM production pathway (see review in Carlson 2002). Viral lysis can 
release large amounts of DOC under bloom conditions (e.g., $~ 50 \%$ more than non-infected bloom; Gobler et al 1997) but more studies are needed to assess this material's lability under different environmental settings (e.g., bloom organisms, nutrient state, light regime). Predation by bacteria has been little studied in the marine environment but may play a role in grazing of particle-associated bacteria (e.g., Banning et al. 2010) and in DOM solubilization from sinking particulate organic matter (POM). In short, more work is needed to constrain the impact of mortality-related processes on DOM composition, given the central role that predation plays in the marine carbon cycle.

\section{DOM ASSIMILATION}

In contrast to DOM production, significantly more information is available on the types of compounds that are assimilated by marine microorganisms as growth substrates or factors. The role of these compounds in sustaining microbial growth or in determining microbial community structure has been explored with two types of studies: compound-based studies and source-based studies. In compound-based studies, a pulse of an individual compound or compound class (e.g., glucose, amino acids) is added, whereas in source-based studies, DOM collected from a particular source (e.g., surface ocean water, marsh grass exudates) is added. In both study types, the growth of all microbes or of selected species is monitored over time. When phylogenetic information is incorporated, it is generally done at the phylum level, with specific emphasis on the $\alpha-, \beta-$, and $\gamma$-proteobacteria as well as the Bacteroidetes (formerly known as the Cytophaga-Flavobacteria-Bacteroidetes, or CFBcluster). These four phyla dominate bacterial counts and clone libraries in the ocean, with varying relative contributions across different nutrient and light regimes. In some cases, the Archaea and the $\alpha$-proteobacterial clades of Roseobacter and SAR11 are also distinguished.

\section{COMPOUND-SPECIFIC UPTAKE}

The choice of substrate for compound-specific studies is challenging. On one hand, Amon \& Benner (1994) showed that HMW DOM was more available for bacterial utilization than LMW DOM, even though HMW DOM was the minor fraction of DOM $(\sim 30 \%)$. On the other hand, monomers are small enough to pass through the cellular membrane for direct 
assimilation. As a result of this conundrum, studies using HMW (polymeric) DOM and those using monomeric DOM are both present in the literature (Table 2). In the first case, incubations with protein, starch, and peptidoglycan have shown that these compound classes are degraded by microbial communities (Keil \& Kirchman 1993, Nagata et al. 2003, Pinhassi et al. 1999), with resulting shifts in community composition and increases in extracellular enzyme activities (Pinhassi et al. 1999). A key result of these studies is that the communities accustomed to HMW DOM utilization may be very different from those adapted to using LMW DOM. Shifts in bacterial community composition have been observed in incubations with proteins and starch (Pinhassi et al. 1999) as well as in incubations with HMW versus LMW dissolved DNA (Lennon 2007). These shifts may occur because organisms using HMW compounds must produce extracellular enzymes to first break HMW material into accessible fragments. Due to the prevalence of cellular material such as carbohydrates and proteins in HMW DOM, enzymatic cleavage of biopolymers has been extensively studied by a number of research groups (e.g., (Pantoja et al 1997) Arnosti et al. 2005, Hoppe et al. 1988). Enzymatic activity and target-breadth appears to depend on a number of different factors, including latitude (Arnosti et al 2005), substrate size (Pantoja \& Lee 1999), substrate structure (Arnosti et al. 2005), and possibly community composition (Arnosti et al. 2005). Despite extensive study of this process, the composition of material remaining after hydrolysis is virtually unknown and remains an area of active study.

\section{<COMP: PLEASE INSERT TABLE 2 HERE $>$}

In contrast to HMW-DOM-utilization studies, monomer-utilization studies have generally focused on small molecules that are ubiquitous in cellular biomass, such as glucose, amino acids, dimethylsulfopropionate (DMSP), adenosine triphosphate (ATP), glycine betaine, and vanillic acid (Table 2). Amino acids are the dominant building blocks of proteins and are easily assimilated directly into cells through dedicated transport systems. However, they are present in low concentrations in marine DOM and are likely available only from transient pulses of labile material (Fuhrman 1987). $\alpha$-proteobacteria appear to be very important competitors for amino acids in the ocean (Cottrell \& Kirchman 2000). Within the $\alpha$-proteobacteria, the SAR11 clade dominates amino acid uptake in the surface 
ocean (Alonso-Saez et al. 2007; Malmstrom et al. 2004a, 2005), even though this group is less able to assimilate proteins (Malmstrom et al. 2005). In one study, SAR11 assimilation of amino acids and Prochlorococcus biomass were correlated, suggesting a tight coupling between heterotrophs and autotrophs in oligotrophic settings (Alonso-Saez et al. 2007). In some coastal environments, the Roseobacter clade is equally as important as SAR11 (or moreso) in amino acid uptake (Alonso-Saez \& Gasol 2007). At higher concentrations, $\gamma$ proteobacteria and Bacteroidetes also play a role in amino acid assimilation, consistent with the view of them as opportunistic organisms (Alonso-Saez \& Gasol 2007, Alonso \& Pernthaler 2006). Lastly, Archaea are able to assimilate amino acids and can make up almost half of the amino acid--assimilating cells in the open ocean (Ouverney \& Fuhrman 2000, Teira et al. 2006).

Another common compound under investigation is glucose, a monomer of complex sugars, which has been shown to be prevalent in the marine environment (Kirchman 2003). Again, $\alpha$-proteobacteria are important players in the glucose cycle (Alonso-Saez \& Gasol 2007, Alonso \& Pernthaler 2006, Malmstrom et al. 2005), although the relative contributions of different phyla appear to be concentration-dependent. Roseobacter dominated glucose uptake at high concentrations, whereas SAR11 dominated at low concentrations (Alonso \& Pernthaler 2006). In addition, Bacteroidetes became increasingly important at high substrate concentrations. Combined with the amino acid results, these data suggest that different clades and phyla are adapted to the low but persistent concentrations of carbon and nitrogen compounds in the oligotrophic ocean (e.g., SAR11) relative to the high but variable concentrations of carbon and nitrogen compounds in the coastal ocean (e.g., Roseobacter and Bacteroidetes).

Sugar- and amino acid - uptake studies dominate the DOM-assimilation literature due to their importance in DOM composition and microbial metabolic requirements. Nonetheless, uptake of a few other compounds has been studied to gain insights into other metabolic needs or aspects of the DOM cycle (Table 2). The utilization of DMSP (an osmolyte; Malmstrom et al. 2004b, Mou et al. 2008, Vila-Costa et al. 2006), glycine betaine (an osmolyte; Mou et al. 2007, 2008), vanillic acid (a lignin phenol; Mou et al. 2007, 2008), ATP (Alonso-Saez \& Gasol 2007), purines, and pyrimidines (Berg \& Jørgensen 2006, Lennon 2007) have all been studied. All of these compounds are taken up by bacteria to 
some extent. The $\alpha$-proteobacteria are involved in uptake of all of these compounds but dominate assimilation of only vanillic acid (and DMSP in some settings; Malmstrom et al. 2004b). In contrast, the $\gamma$-proteobacteria, and to a lesser extent, the $\beta$-proteobacteria and Bacteroidetes, were important users of DMSP, glycine betaine, ATP, and dissolved DNA.

Many of these experiments rely on radiolabeled compound assimilation or on broad (phylum-level) phylogenetic probes to assign uptake of compounds to a microbial group. Depending on the length of incubation, secondary metabolites can be generated and their assimilation by other microbes could lead to an overestimation of primary substrate incorporation. In addition, phylum-level diversity assessments may be too broad phylogenetically to discern genomic differences that define ecotypes or different phylotypes. For example, Kirchman et al. (2005) observed that Cytophaga-like physiology was too broad (or too plastic) to be accurately assessed with phylogeny alone. Indeed, significant subphylum variability in compound assimilation is a common observation in many studies (Lennon 2007, Mou et al. 2007, 2008). Thus, substrate-specific studies may provide insights on the general DOM-assimilation characteristics of a phylum but may be too coarse to discern subtle spatial or temporal phenotypic differences.

\section{SOURCE-SPECIFIC UPTAKE}

Single-compound-utilization studies have been very useful because the composition of the substrate is obviously well defined. In the environment, however, microbes are surrounded by a complex mixture of compounds with a heterogeneous and temporally variable composition. In order to more closely replicate this condition, many investigators have examined microbial utilization of complex substrates (Table 3). These studies examine the fate of DOM from specific sources, such as phytoplankton exudates, or DOM from different regions in the ocean. As numerous good reviews exist (Carlson 2002, Nagata 2008), I focus here on studies published since 2000 that use culture-independent microbiological techniques to monitor microbial diversity.

DOM derived from photosynthesis (or primary production) adds labile material to the surface ocean; this material is remineralized $(\sim 90 \%)$ by heterotrophs within an efficient microbial loop (Azam et al. 1983). Based on bulk elemental ratios, Hopkinson \& Vallino (2005) predicted that N- and P-rich DOM is quickly recycled and remineralized in this loop, 
relative to the C-rich refractory pools. Thus DOM provides essential elements to surface microbial consortia. A small fraction of DOM (likely the C-rich fraction) escapes full remineralization and is transported to the deep ocean (see review in Carlson 2002). This escaping material is partially labile and is further degraded by deepwater consortia during transport (Carlson et al. 2004). Indeed, it appears that surface microbial communities are specifically adapted to highly-labile DOM and are not limited by inorganic nutrients.

Instead, they use a specific fraction of this material (e.g., amino acids; Cherrier \& Bauer 2004) and leave the rest for degradation by deepwater microbes (Carlson et al. 2004). Some studies have postulated microbial utilization of refractory DOM (Cherrier et al. 1999), but the composition of neither DOM nor microbes was determined.

Since the Carlson et al. (2004) study, others have used more phylogenetically specific tools to identify microbes associated with photosynthetic DOM degradation in the surface ocean. In these studies, bulk carbon or bacterial respiration parameters were quantified, but few studies have incorporated DOM compositional information. Nonetheless, some common themes have emerged from these papers. First, $\alpha$-proteobacteria appear to be important in DOM degradation in all studies, although the phylogenetic distinctions between the SAR11 and Roseobacter clades were not always measured [Alonso-Saez et al. 2007 (SAR11 and Roseobacter), Rink et al. 2007 (Roseobacter), Teira et al. 2008 (clades not specified)]. Second, $\gamma$-proteobacteria and Bacteroidetes were more important in all productive areas, relative to oligotrophic ones (Alonso-Saez et al. 2007, Rink et al. 2007, Teira et al. 2008). Lastly, community composition was distinct between nutrient-rich and nutrient-poor regimes, as well as between particle-associated and free-living consortia.

In contrast to surface ocean studies, Covert \& Moran (2001) examined the impact of HMW and LMW estuarine DOM on bacterial community composition. This material is likely to be terrestrially derived with a significant lignin component, although the exact composition of the enrichment medium was not determined. In these experiments, the LMW material was used more quickly and to a greater extent than the HMW material, and unique bacterial communities developed in each enrichment. In the LMW enrichment, the community was dominated by the $\gamma$ - and $\varepsilon$-proteobacteria, with a minor contribution from $\alpha$-proteobacteria (primarily Roseobacter). In contrast, the HMW enrichment was more diverse, with contributions from the $\alpha-, \beta$-, and $\gamma$-proteobacteria as well as the 
Bacteroidetes. Many of the identified organisms were related to those with documented capabilities for lignin degradation, consistent with the anticipated composition of this material.

\section{MICROBIAL COMMUNITIES AND PREDICTED DOM INTERACTIONS}

Identification of critical microbe--DOM interactions will be possible when we describe more fully both the microbial and DOM complexity in the environment. However, this is not feasible with existing techniques. DOM assimilation studies are hampered by substrate oversimplicity or undescribed complexity. In addition, broad, phylum-level microbial diversity assessments do not predict or reflect variability in phenotype. One way to address this impasse is to examine the types of DOM molecules that microbes are equipped to assimilate or to utilize. This metabolic potential can be estimated by mining the genome sequence data that have been acquired for selected species as well as for environmental consortia.

\section{MICROBIAL METABOLIC POTENTIAL: GENOME SEQUENCE INFORMATION}

The recent acquisition of genome sequence information, both from single species (or isolates) and from larger consortia or communities, has provided a wealth of information about metabolic potential in marine systems. These sequences, together with known biochemistry from similar organisms, have provided insights into the metabolic pathways that may be active within the marine environment. The challenge, now, is to assess which pathways are indeed expressed in the environment and under what circumstances. Theoretically, genomics provides the blueprints for all possible metabolic pathways in individual microbes or in complex consortia. So-called -omics techniques build on this information by generating databases of RNA transcripts (analyzed in transcriptomics studies), of proteins (analyzed in proteomics studies), and of metabolites (analyzed in metabolomics studies). The potential for informative, process-oriented studies is immense when you consider how much metabolic information is embedded in the emerging genomic data. Yet, few DOM--microbe studies take advantage of this new information, likely because genomic information is not always presented or available in a format that is clear or 
accessible to geochemists and the lack of gene expression dynamics limits these data's utility in biogeochemical process-studies. Nonetheless, one can focus on specific features of genomes and gain some predictive insights into DOM--microbe interactions. Unlike DOM assimilation, DOM production is affected by the presence of other microbes, including predators, making it impossible to comprehensively predict DOM production from genome sequences alone, particularly in a mixed consortium. Here, I focus on one aspect of DOM-microbe interactions, the membrane transport proteins, a primary DOM assimilation mechanism in microbial cells. Examining the expression and activity of these proteins could be a first step toward building hypotheses that can be tested chemically and biologically in the lab and the field.

\section{SINGLE GENOMES}

Heterotrophic organisms are particularly interesting because they rely on DOM uptake for all their carbon requirements. Bacteria whose genomes have been sequenced (and published prior to May 2010) include Silicibacter pomeroyi (Moran et al. 2004), a member of the Roseobacter clade of the $\alpha$-proteobacteria; Candidatus P. ubique (Giovannoni et al. 2005), a member of the SAR11 clade of the $\alpha$-proteobacteria; Gramella forsetii (Bauer et al. 2006) and Polaribacter sp. MED152 (González et al. 2008), two members of the Bacteroidetes; and Pirellula sp. strain 1 (Glöckner et al. 2003), a member of the Planctomycetes. As mentioned above, the $\alpha$-proteobacteria SAR11 and Roseobacter are ubiquitous organisms in both coastal and open ocean environments, and they play central roles in the carbon cycle in these regions. As free-living organisms, these two groups are adapted for dilute, heterogeneous growth substrates and contain the genes for a relatively high number of ATPbinding cassette systems (ABC transporters) (Giovannoni et al. 2005, Moran et al. 2004). Both genomes contain $\mathrm{ABC}$ transporters for osmolytes such as glycine betaine and DMSP; for small DON compounds such as urea, amino acids, putrescine, and spermidine; and for small carboxylic acids such as glyoxylate and acetate (Table 2). The presence of these transporters in both genomes is consistent with environmental data showing that these two groups coexist in many regions and play similar roles in DOM uptake. However, the two groups appear to have some differences in their target compounds. For example, the genome of S. pomeroyi contains transporters for peptides, whereas the P. ubique genome contains 
transporters for proline and mannitol. The relative distribution of $\mathrm{ABC}$ transporter types has been used to infer that $S$. pomeroyi is more adapted to using transient nutrient pulses relative to P. ubique (Poretsky et al. 2010), which is consistent with other field data (Buchan et al. 2005, Treusch et al. 2009). In contrast, G. forsetii, Polaribacter sp., and Pirellula sp. are thought to prefer an attached lifestyle on particle surfaces. This is reflected in the G. forsetii and Polaribacter sp. genomes by the presence of numerous glycolytic and proteolytic enzymes with transmembrane domains (Bauer et al. 2006, González et al. 2008). Presumably HMW material is broken down outside the cell and the degradation products are then assimilated. There are no data from the genomes to indication that internal utilization of HMW material is possible. Pirellula sp. is proposed to use membraneassociated sulfatases to cleave carbohydrate moieties from extracellular sulfated glycopolymers such as mucin (Glöckner et al. 2003).

Autotrophic organisms (both bacteria and eukaryotes) contain DOM assimilation pathways in their genomes as well. Prochlorococcus genomes contain DON uptake capabilities, specifically urea and oligopeptides for both MED4 and MIT9313, with additional transporters for cyanate in MED4 and for amino acids in MIT9313. The genome of the low-light-adapted Prochlorococcus strain (MIT9313) also contains sugar transporters (Rocap et al. 2003). Both Synechococcus genomes have evidence of DON transporters, specifically, those for urea and amino acids (Palenik et al. 2003, 2006). The genome of the open ocean Synechococcus isolate (WH8102) contains cyanate and phosphonate transporters (Palenik et al. 2003), and the coastal ecotype (CC9311) genome contains small carboxylic acid transporters (Palenik et al. 2006). The eukaryote, Thalassiosira pseudonana, has the genetic capability to use DON molecules such as urea, amino acids, and purines, as well as some sugars (Armbrust et al. 2004). From these aggregated data, it is clear that autotrophic organisms may rely on DOM and thus play a role in its modification in addition to their role in its production.

Besides strict autotrophs and heterotrophs, organisms with putative mixotrophic metabolisms can also assimilate DOM. For example, recent genome work using an uncultured nitrogen-fixing bacterium (UCYN-A; Tripp et al. 2010) shows significant dependency on DOM through a requirement for exogenous sugars, dicarboxylic acids, amino acids, and some polyamines. This work highlights the power of single-cell genome 
sequencing, particularly as it is used to explore the metabolic capabilities of organisms that have not been isolated in laboratory culture. Lastly, we are woefully unaware of DOM production (or assimilation) mechanisms in the Archaea. Many of these organisms are presumably autotrophs, fixing carbon through ammonia oxidation. However, their lipids show that a portion of these populations acquires carbon through heterotrophic processes (Ingalls et al. 2006); therefore, the impact of these organisms on DOM assimilation or production is poorly constrained. The genome of Cenarchaeum symbiosum, a symbiont and member of the Crenarchaeota, contains genes for carbohydrate, amino acid, and nucleotide transporters as well as genes for secondary metabolite synthesis and urea remineralization (Hallam et al. 2006). Similarly, the genome of the free-living Nitrosopumilus maritimus, a member of the Crenarchaeota, contains transporters for amino acids, oligopeptides, and phosphonates (Walker et al. 2010). As with all genomes, the link between genetic capability and environmental metabolic function must be established to further assess the role of these organisms in DOM assimilation.

\section{COMMUNITY GENOMES: METAGENOMICS, FUNCTIONAL GENES}

Because the majority of marine microbes has eluded isolation and cultivation to date, environmental metagenomics, or the sequencing of genomic DNA from environmental consortia, has been used to assess the metabolic potential of the "unculturable" majority. One of the first attempts to do this in the oceans was the Global Ocean Sampling Expedition (GOS; Rusch et al. 2007, Venter et al. 2004). This group collected environmental DNA from many sites across the ocean, spanning a significant range of latitudes and longitudes, as well as coastal and oligotrophic regimes. In theory, the metagenome is the genome of the entire consortium, providing a complete map for the metabolic pathways within the microbial community. In practice, this approach works well only in communities with limited diversity (e.g., acid mine drainage communities; Tyson et al. 2004). In the marine environment, many communities have high diversity, thus full community genomes cannot be assembled. As with single-isolate sequencing, much of the focus of environmental sequencing has been on DOM acquisition and assimilation rather than on DOM production. In the surface ocean, genes for phosphonate uptake (Venter et al. 2004) and for DON incorporation (amino sugars, purines, pyrimidines; DeLong et al. 2006) are present or 
enhanced. In contrast, genes associated with polysaccharide degradation were enhanced in the deep ocean (DeLong et al. 2006). These studies are consistent with other evidence showing phosphonate production in the surface ocean and degradation of relatively recalcitrant polysaccharides in POM at depth.

Another way to assess metabolic potential on a broader scale is the amplification of specific functional genes from community DNA. Two recent examples involve the genes necessary for urea and glycolate degradation. Both molecules are products of microbial metabolism: Urea is a common waste product of DON remineralization and glycolate is a by-product of carbon fixation. The enzymes needed for urea and glycolate degradation are urease and glycolate oxidase, respectively. Primers for the urease gene (ureC) uncovered an unprecedented diversity of urea-degrading microbes in estuarine and open ocean environments. Over half of the amplicons did not correspond to known utilizers of urea, suggesting that the use of urea may be more widespread among the microbial community than previously considered (Collier et al. 2009). This is consistent with the presence of urea transporters in many sequenced genomes (Table 2). Similar results were observed with primers for the glycolate oxidase gene $(g l c D)$. This gene was present in both coastal and open ocean environments, but its diversity was different between the two regions, presumably due to the different resident phytoplankton communities and their variable production of glycolate (Lau \& Armbrust 2006). The gene was detected in phylogenetically unrelated bacterial groups, and many amplicons were placed within novel clades with no cultured representatives. In both of these examples, further work is needed to confirm that genetically-similar amplicons are expressed in situ and that they have the same metabolic function as their homologues in laboratory organisms.

\section{EXPRESSION OF SPECIFIC GENES: TRANSCRIPTOMICS AND PROTEOMICS}

Genomics provides an overview of metabolic potential through the identification of the genes required for particular metabolic pathways. The transcription of selected genes into messenger RNA is the first step toward the initiation of specific pathways. Proteins are then synthesized according to the transcribed genes and used to catalyze the chosen metabolic processes. Both messenger RNA and proteins have fairly short (and variable) lifetimes in cells, so their presence is considered to be indicative of processes in current use by the 
cell(s). Applications of transcriptomics and proteomics are just beginning in the marine sciences, but they are already shedding light on DOM--microbe interactions. In the lab, Zinser et al. (2009) observed diel periodicity in the majority of annotated genes of Prochlorococcus MED4, consistent with the notion that these organisms focus on photosynthesis during the day and respiration during the night. In the field, Poretsky et al. (2009) compared transcripts in the day and night of the surface Pacific Ocean (Station ALOHA). Transporters for amino acids were more highly expressed at night, although transporters for urea, amino acids, polyamines, and phosphonates were generally present throughout the diurnal cycle. This suggests that DOM acquisition is an important process at all times, with some variability associated with organisms containing light-driven metabolisms (e.g., cyanobacteria). A similar analysis was used to follow transport protein transcripts in a coastal system, as a function of DOM source (ambient, phytoplanktonderived, and plant-derived) (Table 3). Here, Roseobacter, SAR11, and Flavobacteria (phylum Bacteroidetes) dominated the acquisition of DOM monomers, with minor contributions from the $\gamma$-proteobacteria (Poretsky et al. 2010). Interestingly, the relative contributions of genes associated with these three bacterial groups changed as a function of DOM source. Roseobacter was always important, consistent with the emerging hypothesis that this clade is well adapted to transient nutrient pulses. However, SAR11 transporters were more important during incubations with phytoplankton-derived DOM, presumably due to their relatively high complement of carboxylic acid transporters, relative to carbohydrate and sugar transporters. In contrast, flavobacterial transporters were more important during incubations with plant-derived DOM, presumably due to their relatively high complement of carbohydrate transporters.

Proteomics and metaproteomics approaches have also shown significant metabolic variability associated with different nutrient and light conditions (Morris et al. 2010, Sowell et al. 2009). As might be hypothesized from genomic and field studies, the proteome of $P$. ubique shows a high complement of transport proteins, particularly for amino acids and reduced sulfur compounds (Sowell et al. 2008). The metaproteome collected from the Bermuda Atlantic Time Series (BATS) station was recently analyzed in the context of predictions from SAR11, Prochlorococcus, and Synechococcus genomes (Sowell et al. 2009). Many of the SAR11 transport proteins for sugars, amino acids, and phosphonates 
were detected in this sample, suggesting that these organisms (or similar ones) were actively acquiring DOM compounds at the time of sampling. Likewise, Morris et al. (2010) showed that transport proteins were a dominant fraction of expressed membrane-associated proteins along a marine nutrient gradient. The specificity of these transporters is not well constrained, but their high diversity suggests that cells are able to respond to a broad range of substrates (Morris et al. 2010).

\section{MICROBIAL METABOLIC POTENTIAL: PLASTICITY OF PHYLOGENETIC PREDICTIONS}

Three of the big unknowns when it comes to interpreting (or extending) genomic data are the degree to which genome sequences are shared within individual clades, whether organisms can use all the weapons in their metabolic arsenal, and under what conditions they are deployed. Many microbe--DOM studies have used broad phylogenetic distinctions to examine the roles of different phyla in DOM cycling. However, culture studies (Prochlorococcus; Moore et al. 2002), genomic sequencing (Synechococcus; Palenik et al. 2003, 2006), and field work (Carlson et al. 2009) have shown that even isolates from the same clade can have very different physiological and functional capabilities and can correlate with different environmental parameters. Thus, DOM assimilation capabilities highlighted in whole genomes or in metagenomes may not be conserved or expressed similarly across a phylum. For example, a modified glycolysis operon that confers the ability to assimilate glucose was not conserved across all isolates of the SAR11 clade (Schwalbach et al. 2010). Even though the presence of this operon appeared to be correlated with high productivity in the GOS data set, it did not confer a broad capability to assimilate sugar monomers in laboratory culture. In short, widespread physiological diversity within a clade may or may not be reflected in genomic diversity among clade members.

One possible explanation for phenotypic diversity could be differential expression of genes under changing environmental conditions. Some work has highlighted latitudinal and temporal variabilities in community structure that are retained over large spatial and temporal scales (Fuhrman et al. 2008), suggesting some predictive response to environmental forcing or the presence of ecological functioning units. A related question could be whether marine bacteria operate as generalists with many transporters present 
simultaneously or as specialists with a few, but highly specific, transporters present under unique conditions. Early work indicated that bacterial consortia contain a mixture of generalists and specialists, with redundant ecological functioning [Findlay et al. 2003

(freshwater), Langenheder et al. 2005 (seawater)]. Bulk ecological functions such as bacterial biomass and respiration were weakly related to bacterial community composition in these studies, suggesting significant redundancy in these parameters (Langenheder et al. 2005, 2006). In contrast, compound-specific ecological functions such as enzyme activities or compound degradation varied as a function of bacterial composition, highlighting the role of community composition in specific ecosystem parameters (Langenheder et al. 2006). Subsequent work with metagenomics and transcriptomics corroborate these early results. In the coastal system where transient DOC pulses are common but vary in composition, bacteria act as generalists and consortia have significant functional redundancy (Mou et al. 2008, Poretsky et al. 2010). Species variability in transporter distributions affects relative species composition during a pulse (Poretsky et al. 2010), and top-down controls may play important roles in species diversity (Mou et al. 2008). In the open ocean, where DOC pulses are less frequent and composition may be less variable, other environmental factors dominate, and significant latitudinal (Fuhrman et al. 2008) and depth (Treusch et al. 2009) variations in community composition are observed. Here, organisms may be more likely to operate as specialists and can expend more energy to develop novel systems of DOM assimilation (Giovannoni et al. 2005, Sinsabaugh \& Findlay 2003).

\section{WHERE DO WE GO FROM HERE?}

To date, DOM characterization studies and microbial utilization studies are difficult to reconcile because they have essentially focused on different pools of material. DOM is dilute and heterogeneous and thus very difficult to extract quantitatively from the salty seawater matrix. Much of the descriptive work on DOM composition (e.g., Aluwihare et al. 1997, McCarthy et al. 1998) has been done on HMW material that is not directly available for biological assimilation. From the perspective of microbial utilization, many of the studies have used small molecules such as amino acids or glucose as proxies for bioavailable DOM, due to their recognized importance as microbial growth substrates and to the ease of acquisition from chemical vendors. These molecules are not quantitatively 
significant in the DOM pool, but they may have very low residence times and high fluxes due to their biological lability. Indeed, the production and assimilation of reactive monomers may be so tightly coupled that these compounds never accumulate in the DOM pool (Fuhrman 1987). Less reactive compounds may accumulate to varying degrees in DOM and thus would be available for microbial assimilation. Below, I propose five research directions that would help unravel DOM--microbe interactions.

\section{LOW-MOLECULAR-WEIGHT DOM}

As evidenced by the biological focus of the preceding review, descriptions of metabolic potential have progressed more quickly than description of available DOM compounds. With recent advances in mass spectrometry and related techniques, organic biogeochemists will be able to provide more comprehensive assessments of the small polar molecules in DOM, or those most likely to be directly assimilated into marine microbes. However, these techniques have been applied to only a few environments to date (Figure 3) with limited sample sets. Many studies have focused on the coastal system or terrestrial margins, presumably due to proximity to research centers and the cost of oceangoing vessels. Nonetheless, a more comprehensive study of this material should be undertaken with a focus on regions of proposed microbial differences. For example, a systematic analysis of deepwater DOM has not been conducted, nor of DOM differences within a redox zone. Once we understand the bounds of variability of this important pool, we can develop hypotheses about the impact of DOM composition on microbial function in these different environments.

\section{DOM PRODUCTION PROCESSES}

One of the knowledge gaps highlighted in this review is the molecular-level nature of DOM produced by microbes, either exuded during growth stages or released by grazing or lysis. While previous work has addressed this question from the perspective of biological monomers, more work is needed to examine other pools of exudates and lysis products. To close this gap, we need to understand the suite of DOM molecules present within cells as well as the selection processes that govern their exudation or release. In the first case, we 
need to characterize internal and external metabolites as a function of growth stage, nutrient condition, light, and other environmental parameters (e.g., Barofsky et al. 2009, RosselloMora et al. 2008). We must also assess the impact of cocultured organisms on these metabolite profiles as there is ample evidence in the literature of synergistic or antagonistic effects of exuded DOM on cocultured microbes (Morris et al. 2008, Paul et al. 2009). Lastly, we need to examine the impacts of predation processes, broadly defined as the death of one cell through the action of external agents, on both DOM composition and prey diversity (Alonso-Saez et al. 2009). This will include protozoan grazing (Nagata \& Kirchman 1990), viral lysis (Gobler et al 1997)(Nagata 2000), and bacterial predation. All of these processes may exert different selection pressures on DOM released during the predation event. Consideration of these effects will require coculture experiments as well as quasi-controlled field incubations.

\section{SUBSTRATES AND SUBSTRATE-SPECIFICITY OF MEMBRANE TRANSPORT PROTEINS}

As new sequencing technologies develop with less bias and greater coverage (Brown et al. 2009, Sogin et al. 2006), new genes are continuously discovered in new microbial species and novel environments (Frias-Lopez et al. 2008). All genomes published to date have hypothetical genes or genes with unknown function. Many of these genes are expressed in the environment (Frias-Lopez et al. 2008) and so are presumed to be active in microbial metabolisms. Tringe et al. (2005) found that many uncharacterized genes and processes were critical to separating Sargasso Sea metagenomes from whale fall and soil metagenomes. This suggests that unique lifestyles and/or metabolic pathways have evolved in these systems that confer some environmental advantage. Linking these genes with specific metabolic functions can be a challenge due to difficulties with gene and genome annotations. Most genes are annotated based on homology between the unknown gene and genes listed in online databases, and unknown gene function is assumed to be similar to that of the homologous gene. A more direct way to assess gene function is to clone it, to express it in a host organism, and then to test gene function directly. This method is impractical for all genes within a target organism but has been used for biogeochemically interesting gene 
operons such as proteorhodopsin (Béjà et al 2000) and the operon associated with DMSPDMS transformations (Todd et al. 2010).

Annotation challenges are exacerbated in the case of transport proteins. In order to generate hypotheses based on transport protein presence and function, a chemist needs to know which compounds are targeted by the protein and the specificity and binding efficiency of the protein for that substrate. Many annotations in the literature are vague and fairly undefined. For example, it is common to see a transporter annotated by compound class (e.g., sugar transporter). However, this generality invites a number of questions: Can the transporter assimilate all sugar monomers? Or is its specificity limited to hexoses? Or is it limited to one monomer such as glucose? To constrain these parameters, detailed biochemical studies such as binding assays are needed for highly expressed transport proteins. In addition, characterization of unknown or unannotated proteins is required. It is possible that new or unique metabolic capabilities are conferred by these unknown genes.

\section{INTEGRATION OF -OMICS STUDIES}

In order to understand and predict microbial metabolism in the oceans, one needs to examine the microbe-environment interaction from a holistic perspective. All the -omics fields are linked together and provide different insights into cellular metabolism (Figure 4). Genomics provides a map of metabolic potential, but transcriptomics is necessary to convert this potential into a map of metabolic expression. Proteomics then provides an assessment of metabolic activity from the enzyme/protein level, and metabolomics integrates metabolic processes through the characterization of metabolic intermediates. To date, these integrated studies (also known as systems biology) are difficult to conduct in marine systems but are starting to appear in other environmental settings (e.g., acid mine drainage community; Ram et al. 2005, Tyson et al. 2004). In the marine sciences, we have spent a lot of time and energy on the genomics and transcriptomics portion of this picture but relatively less effort on proteomics or metabolomics. This focus is due primarily to analytical challenges associated with these downstream analyses. Unlike DNA, proteins cannot be amplified and are often present in low concentrations. In addition, specialized instrumentation and computing tools are needed to take full advantage of the data's complexity. Metabolomics is one more step along this path but is even more complicated than proteomics. The elemental 
building blocks of metabolites are more complex (atoms rather than amino acids) and their physicochemical properties are quite diverse. Nonetheless, techniques are evolving to plumb and understand this chemical diversity in the context of biochemical studies and environmental applications. Full integration of these studies within marine settings will be critical to obtaining new insights on microbe--molecule interactions.

A good first step would be the combination of chemical studies with microbiological studies such as genomics or proteomics. There are no studies (to my knowledge) that incorporate a broad assessment of genomic or proteomic capability with molecular-level characterization of DOM (Figure 3). Work of this nature could provide the molecular underpinnings of the ecological functioning units described by Langenheder et al. (2006) and the complex networks proposed by Fuhrman \& Steele (2008) and Fuhrman et al. (2008). In addition, it could help elucidate novel metabolisms represented by genes with hypothetical functions, and it could highlight regions of misannotation or modified metabolism. Thus, this work could be an important step toward linking genes to environmental function. Similar calls for ecosystems biology have been proposed by numerous reviews (Azam \& Malfatti 2007, Azam \& Worden 2004, Foreman \& Covert 2003, Kirchman 2003, Nagata 2008, Strom 2008).

\section{NEW COMPUTATIONAL TOOLS}

As we move forward with integrating emerging techniques in both analytical chemistry and microbiology, it is important to consider new computational tools that may further these goals. The most critical tools that need to be developed are the bioinformatic techniques that will help integrate the results of -omics studies. Online tools such as processing algorithms or databases are in different stages of completion for the various -omics tools. Genomics is the furthest ahead and proteomics databases are not far behind, but these databases need to be well curated to include emerging experimental data on gene and protein function. At the same time, we need tools to integrate these databases and to establish data connections that yield testable hypotheses. Lastly, we need to collaborate with computer scientists, data managers, and modeling experts to generate realistic metabolic models for single microbes and complex consortia (Haruta et al. 2009, Vallino 2010) that explore shifts in metabolic capabilities along environmental gradients (Follows et al. 2007, Gianoulis et al. 2009). 
These models could then guide biochemical studies and field studies to explore areas of uncertainty in these fundamental reactions of the carbon cycle.

In conclusion, we stand on the precipice of a revolution in our understanding of the microbe--molecule interactions that sit at the base of the global carbon cycle. With advances in analytical chemistry, molecular microbiology, and computer informatics, we will be able to establish direct links between microbes and their environment in an unprecedented way.

\section{SUMMARY POINTS}

1. Due to its compositional heterogeneity, DOM is difficult to extract from seawater and challenging to characterize on a molecular level.

2. Although it is the minor component $(\sim 30 \%)$ of DOM, the HMW (>1000 Da) fraction is the best-characterized portion of DOM due to analytical feasibility. Emerging techniques based on electrospray ionization coupled to mass spectrometry may shed light on composition of the LMW fraction of DOM.

3. DOM is produced through microbial activities that include photosynthesis, heterotrophic metabolism, and predation. The composition of DOM produced by each of these processes is poorly constrained (Table 1).

4. DOM is consumed or altered by microbial activities as well. A combination of compound-specific and source-specific uptake experiments have provided insights into the suite of compounds assimilated by marine microbes (Tables 2,3 ).

5. Genomic sequence information from individual species and from environmental consortia is providing a good starting point for assessment of DOM assimilation capabilities of selected organisms (Table 2).

6. Transport proteins are the portals for DOM assimilation into cells, and the identification and characterization of these proteins in situ will help establish the breadth of DOM molecules available for assimilation and utilization by microbes.

7. Integrated studies that include DOM characterization and microbial diversity assessments will foster new understanding of the DOM--microbe interactions that serve as the molecular foundation to the marine carbon cycle.

\section{FUTURE ISSUES}


1. Molecular-level characterization of LMW DOM is needed to more fully examine the compositional heterogeneity of this material and to assess its bioavailability towards different microbial processes. These characterization studies should be done in both the laboratory and field settings.

2. The composition of biologically produced DOM is a key gap in our knowledge of DOM cycling in marine systems. To close this gap, we need studies that systematically assess transcripts, proteins, and metabolites (both internal and external) within numerically dominant microbes, both in the presence and absence of predation.

3. Genome annotations for key DOM-assimilating proteins are often too vague (at present) to allow the development of specific, mechanistic hypotheses for DOM-microbe interactions. Thus, the experimental verification of substrate specificity and binding efficiencies is an important step towards validation of genome annotations and elucidation of the relative impact of different microbes on DOM utilization and/or modification.

4. New computational tools and databases are needed to integrate data from disparate research groups with different research foci. In particular, we need tools that allow the development of multispecies metabolic models.

5. Sampling integration between different -omics practitioners is an important step towards developing an ecosystems-biology perspective on the marine carbon cycle.

\section{DISCLOSURE STATEMENT}

The author is not aware of any affiliations, memberships, funding, or financial holdings that might be perceived as affecting the objectivity of this review.

\section{ACKNOWLEDGMENTS}

Although I take responsibility for the ideas presented here, they were formulated through numerous conversations with colleagues within and outside my research group. In particular, Krista Longnecker and Steve Giovannoni have provided insights and corrections 
over the last few years. My research has been funded through the National Science Foundation, the Gordon and Betty Moore Foundation, and Woods Hole Oceanographic Institution internal resources.

\section{LITERATURE CITED}

Allers E, Gomez-Consarnau L, Pinhassi J, Gasol JM, Simek K, Pernthaler J. 2007. Response of Alteromonadaceae and Rhodobacteriaceae to glucose and phosphorus manipulation in marine mesocosms. Environ. Microbiol. 9:2417--29

Alonso C, Pernthaler J. 2006. Roseobacter and SAR11 dominate microbial glucose uptake in coastal North Sea waters. Environ. Microbiol. 8:2022--30

Alonso-Saez L, Aristegui J, Pinhassi J, Gomez-Consarnau L, Gonzalez JM, et al. 2007. Bacterial assemblage structure and carbon metabolism along a productivity gradient in the NE Atlantic Ocean. Aquat. Microb. Ecol. 46:43--53

Alonso-Saez L, Gasol JM. 2007. Seasonal variations in the contribution of different bacterial groups to the uptake of low-molecular-weight compounds in northwestern Mediterranean coastal waters. Appl. Environ. Microbiol. 73:3528--35

Alonso-Saez L, Unanue MA, Latatu A, Azua I, Ayo B, et al. 2009. Changes in marine prokaryotic community induced by varying types of dissolved organic matter and subsequent grazing pressure. J. Plankton Res. 31:1373--83

Aluwihare LI, Repeta DJ. 1999. A comparison of the chemical characteristics of oceanic DOM and extracellular DOM produced by marine algae. Mar. Ecol. Prog. Ser. 186:105--17

Aluwihare LI, Repeta DJ, Chen RF. 1997. A major biopolymeric component to dissolved organic carbon in surface sea water. Nature 387:166--69

Amon RMW, Benner R. 1994. Rapid cycling of high-molecular-weight dissolved organic matter in the ocean. Nature 369:549--52

Arístegui J, Gasol JM, Duarte CM, Herndl GJ. 2009. Microbial oceanography of the dark ocean's pelagic realm. Limnol. Oceanogr. 54:1501--29

Armbrust EV, Berges JA, Bowler C, Green BR, Martinez D, et al. 2004. The genome of the diatom Thalassiosira pseudonana: ecology, evolution, and metabolism. Science 306:79--86 
Arnosti C. 2003. Microbial extracellular enzymes and their role in dissolved organic matter cycling. In Aquatic Ecosystems: Interactivity of Dissolved Organic Matter, ed. SEG Findlay, RL Sinsabaugh, pp. 316--42.San Diego, CA: Academic

Arnosti C, Durkin S, Jeffrey WH. 2005. Patterns of extracellular enzyme activities among pelagic marine microbial communities: implications for cycling of dissolved organic carbon. Aquat. Microb. Ecol. 38:135--45

Azam F, Fenchel T, Field JG, Gray JS, Meyer-Reil LA, Thingstad F. 1983. The ecological role of water-column microbes in the sea. Mar. Ecol. Prog. Ser. 10:257--63

Azam F, Malfatti F. 2007. Microbial structuring of marine ecosystems. Nat. Rev. Microbiol. 5:782--91

Azam F, Worden AZ. 2004. Microbes, molecules and marine ecosystems. Science 303:1622--24

Banning E, Casciotti KL, Kujawinski EB. 2010. Novel strains isolated from a coastal aquifer suggest a predatory role for Flavobacteria. FEMS Microbiology Ecology. 73: 254-270

Barofsky A, Simonelli P, Vidoudez C, Troedsson C, Nejstgaard JC, et al. 2010. Growth phase of the diatom Skeletonema marinoi influences the metabolic profile of the cells and the selective feeding of the copepod Calanus spp. J. Plankton Res. 32:263--72

Barofsky A, Vidoudez C, Pohnert G. 2009. Metabolic profiling reveals growth stage variability in diatom exudates. Limnol. Oceanogr.: Methods 7:382--90

Bauer M, Kube M, Teeling H, Richter M, Lombardot T, et al. 2006. Whole genome analysis of the marine Bacteroidetes 'Gramella forsetii' reveals adaptations to degradation of polymeric organic matter. Environ. Microbiol. 8:2201--13

Béjà O, Aravind L, Koonin EV, Suzuki MT, Hadd A, et al. 2000. Bacterial rhodopsin: Evidence for a new type of phototrophy in the sea. Science 289: 1902-06

Benner R. 2002. Chemical composition and reactivity. In Biogeochemistry of Marine Dissolved Organic Matter, ed. DA Hansell, CA Carlson, pp. 59--90. San Diego, CA: Elsevier

Berg GM, Jørgensen NOG. 2006. Purine and pyrimidine metabolism by estuarine bacteria. Aquat. Microb. Ecol. 42:215--26

Bertilsson S, Jones JB. 2003. Supply of dissolved organic matter to aquatic ecosystems: Autochthonous sources. In Aquatic Ecosystems: Interactivity of Dissolved Organic Matter, ed. SEG Findlay, RL Sinsabaugh, pp. 3--25. San Diego, CA: Elsevier 
Brown MV, Philip GK, Bunge JA, Smith MC, Bissett A, et al. 2009. Microbial community structure in the North Pacific Ocean. ISME J. 3:1374--86

Buchan A, Gonzalez JM, Moran MA. 2005. Overview of the marine Roseobacter lineage. Appl. Environ. Microbiol. 71:5665--77

Buesseler KO, Boyd PW. 2009. Shedding light on processes that control particle export and flux attenuation in the twilight zone of the open ocean. Limnol. Oceanogr. 54:1210--32

Carlson CA. 2002. Production and removal processes. In Biogeochemistry of Marine Dissolved Organic Matter, ed. DA Hansell, CA Carlson, pp. 91--152. San Diego, CA: Elsevier

Carlson CA, Giovannoni SJ, Hansell DA, Goldberg SJ, Parsons R, Vergin K. 2004. Interactions among dissolved organic carbon, microbial processes, and community structure in the mesopelagic zone of the northwestern Sargasso Sea. Limnol. Oceanogr. 49:1073--83

Carlson CA, Morris R, Parsons R, Treusch AH, Giovannoni SJ, Vergin K. 2009. Seasonal dynamics of SAR11 populations in the euphotic and mesopelagic zones of the northwestern Sargasso Sea. ISME J. 3:283--95

Caron DA, Goldman JC, Andersen OK, Dennett MR. 1985. Nutrient cycling in a microflagellate food chain. II. Population dynamics and carbon cycling. Mar. Ecol. Prog. Ser. 24:243--54

Cherrier J, Bauer JE. 2004. Bacterial utilization of transient plankton-derived dissolved organic carbon and nitrogen inputs in surface ocean waters. Aquat. Microb. Ecol. 35:229--41

Cherrier J, Bauer JE, Druffel ERM, Coffin RB, Chanton JP. 1999. Radiocarbon in marine bacteria: evidence for the ages of assimilated carbon. Limnol. Oceanogr. 44:730--36

Collier JL, Baker KM, Bell SL. 2009. Diversity of urea-degrading microorganisms in openocean and estuarine planktonic communities. Environ. Microbiol. 11:3118--31

Cottrell MT, Kirchman DL. 2000. Natural assemblages of marine proteobacteria and members of the Cytophaga-Flavobacter cluster consuming low- and high-molecular-weight dissolved organic matter. Appl. Environ. Microbiol. 66:1692--97

Covert JS, Moran MA. 2001. Molecular characterization of estuarine bacterial communities that use high- and low-molecular weight fractions of dissolved organic carbon. Aquat. Microb. Ecol. 25:127--39

DeLong EF, Preston CM, Mincer T, Rich V, Hallam SJ, et al. 2006. Community genomics among stratified microbial assemblages in the ocean's interior. Science 311:496--503 
Dittmar T, Koch B, Hertkorn N, Kattner G. 2008. A simple and efficient method for the solidphase extraction of dissolved organic matter (SPE-DOM) from seawater. Limnol. Oceanogr.: Methods 6:230--35

Dittmar T, Paeng J. 2009. A heat-induced molecular signature in marine dissolved organic matter. Nat. Geosci. 2:175--79

Dyhrman ST, Benitez-Nelson CR, Orchard ED, Haley ST, Pellechia PJ. 2009. A microbial source of phosphonates in oligotrophic marine systems. Nat. Geosci. 2:696--99

Elifantz H, Dittel AI, Cottrell MT, Kirchman DL. 2007. Dissolved organic matter assimilation by heterotrophic bacterial groups in the western Arctic Ocean. Aquat. Microb. Ecol. 50:39--49

Findlay SEG, Sinsabaugh RL, Sobczak WV, Hoostal M. 2003. Metabolic and structural response of hyporheic microbial communities to variations in supply of dissolved organic matter. Limnol. Oceanogr. 48:1608--17

Follows MJ, Dutkiewicz S, Grant S, Chisholm SW. 2007. Emergent biogeography of microbial communities in a model ocean. Science 315:1843--46

Foreman CM, Covert JS. 2003. Linkages between dissolved organic matter composition and bacterial community structure. In Aquatic Ecosystems: Interactivity of Dissolved Organic Matter, ed. SEG Findlay, RL Sinsabaugh, pp. 343--62. San Diego, CA: Elsevier

Frias-Lopez J, Shi Y, Tyson GW, Coleman ML, Schuster SC, et al. 2008. Microbial community gene expression in ocean surface waters. Proc. Natl. Acad. Sci. USA 105:3805--10

Fuhrman JA. 1987. Close coupling between release and uptake of dissolved free amino acids in seawater studied by an isotope dilution approach. Mar. Ecol. Prog. Ser. 37: 45-52

Fuhrman JA, Steele JA. 2008. Community structure of marine bacterioplankton: patterns, networks and relationships to function. Aquat. Microb. Ecol. 53:69--81

Fuhrman JA, Steele JA, Hewson I, Schwalbach MS, Brown MV, et al. 2008. A latitudinal diversity gradient in planktonic marine bacteria. Proc. Natl. Acad. Sci. USA 105:7774--78

Gasol JM, Pinhassi J, Alonso-Saez L, Ducklow H, Herndl GJ, et al. 2008. Towards a better understanding of microbial carbon flux in the sea. Aquat. Microb. Ecol. 53:21--38

Gianoulis TA, Raes J, Patel PV, Bjornson R, Korbel JO, et al. 2009. Quantifying environmental adaptation of metabolic pathways in metagenomics. Proc. Natl. Acad. Sci. USA 106:1374--79

Giovannoni SJ, Tripp HJ, Givan S, Podar M, Vergin KL, et al. 2005. Genome streamlining in a cosmopolitan oceanic bacterium. Science 309:1242--45 
Glöckner FO, Kube M, Bauer M, Teeling H, Lombardot T, et al. 2003. Complete genome sequence of the marine planctomycete Pirellula sp. strain 1. Proc. Natl. Acad. Sci. USA 100:8298--303

Gobler CJ, Hutchins DA, Fisher NS, Cosper EM, Sañudo-Wihelmy SA. 1997. Release and bioavailability of C, N, P, Se, and Fe following viral lysis of a marine chrysophyte. Limnol. Oceanogr. 42: 1492-504

González JM, Covert JS, Whitman WB, Henriksen JR, Mayer F, et al. 2003. Silicibacter pomeroyi sp. nov. and Roseovarius nubinhibens sp. nov., dimethylsulfoniopropionatedemethylating bacteria from marine environments. Int. J. Syst. Evol. Microbiol. 53:1261--69

González JM, Fernández-Gómez B, Fernàndez-Guerra A, Gómez-Consarnau L, Sánchez O, et al. 2008. Genome analysis of the proteorhodopsin-containing marine bacterium Polaribacter sp. MED152 (Flavobacteria). Proc. Natl. Acad. Sci. USA 105:8724--29

González JM, Whitman WB, Hodson RE, Moran MA. 1996. Identifying numerically abundant culturable bacteria from complex communities: an example from a lignin enrichment culture. Appl. Environ. Microbiol. 62:4433--40

Gram L, Grossart H-P, Schlingloff A, Kiørboe T. 2002. Possible quorum sensing in marine snow bacteria: production of acylated homoserine lactones by Roseobacter strains isolated from marine snow. Appl. Environ. Microbiol. 68:4111--16

Granum E, Kirkvold S, Myklestad SM. 2002. Cellular and extracellular production of carbohydrates and amino acids by the marine diatom Skeletonema costatum: diel variations and effects of N depletion. Mar. Ecol. Prog. Ser. 242:83--94

Grossart HP, Simon M. 2007. Interactions of planktonic algae and bacteria: effects on algal growth and organic matter dynamics. Aquat. Microb. Ecol. 47:163--76

Gruber DF, Simjouw J-P, Seitzinger SP, Taghon GL. 2006. Dynamics and characterization of refractory dissolved organic matter produced by a pure bacterial culture in an experimental predator--prey system. Appl. Environ. Microbiol. 72:4184--91

Hallam SJ, Konstantinidis KT, Putnam N, Schleper C, Watanabe Y-I, et al. 2006. Genomic analysis of the uncultivated marine crenarchaeote Cenarchaeum symbiosum. Proc. Natl. Acad. Sci. USA 103:18296--301

Haruta S, Kato S, Yamamoto K, Igarashi Y. 2009. Intertwined interspecies relationships: approaches to untangle the microbial network. Environ. Microbiol. 11:2963--69 
Höfle MG, Kirchman DL, Christen R, Brettar I. 2008. Molecular diversity of bacterioplankton: link to a predictive biogeochemistry of pelagic ecosystems. Aquat. Microb. Ecol. 53:39--58

Hopkinson CS, Vallino JJ. 2005. Efficient export of carbon to the deep ocean through dissolved organic matter. Nature 433:142--45

Hoppe H-G, Kim S-J, Gocke K. 1988. Microbial decomposition in aquatic environments: combined process of extracellular enzyme activity and substrate uptake. Appl. Environ. Microbiol. 54:784--90

Ingalls AE, Shah SR, Hansman RL, Aluwihare LI, Santos GM, et al. 2006. Quantifying archaeal community autotrophy in the mesopelagic ocean using natural radiocarbon. Proc. Natl. Acad. Sci. 103:6442--47

Ito Y, Butler A. 2005. Structure of synechobactins, new siderophores of the marine cyanobacterium Synechococcus sp. PCC 7002. Limnol. Oceanogr. 50:1918--23

Kawasaki N, Benner R. 2006. Bacterial release of dissolved organic matter during cell growth and decline: molecular origin and composition. Limnol. Oceanogr. 51:2170--80

Keil RG, Kirchman DL. 1993. Dissolved combined amino acids: chemical form and utilization by marine bacteria. Limnol. Oceanogr. 38:1256--70

Kim S, Simpson AJ, Kujawinski EB, Freitas MA, Hatcher PG. 2003. High resolution electrospray ionization mass spectrometry and 2D solution NMR for the analysis of DOM extracted by $\mathrm{C} 18$ solid phase disk. Org. Geochem. 34:1325--35

Kirchman DL. 2003. The contribution of monomers and other low-molecular weight compounds to the flux of dissolved organic material in aquatic ecosystems. In Aquatic Ecosystems: Interactivity of Dissolved Organic Matter, ed. SEG Findlay, RL Sinsabaugh, pp. 218--43. San Diego, CA: Elsevier

Kirchman DL, Dittel AI, Malmstrom RR, Cottrell MT. 2005. Biogeography of major bacterial groups in the Delaware Estuary. Limnol. Oceanogr. 50:1697--706

Koprivnjak JF, Pfromm PH, Ingall E, Vetter TA, Schmitt-Kopplin P, et al. 2009. Chemical and spectroscopic characterization of marine dissolved organic matter isolated using coupled reverse osmosis--electrodialysis. Geochimica et Cosmochimica Acta 73:4215--31

Kujawinski EB, Del Vecchio R, Blough NV, Klein GC, Marshall AG. 2004. Probing molecularlevel transformations of dissolved organic matter: insights from electrospray ionization Fourier-transform ion cyclotron resonance mass spectrometry. Mar. Chem. 92:23--37 
Kujawinski EB, Longnecker K, Blough NV, Del Vecchio R, Finlay L, et al. 2009. Identification of possible source markers in marine dissolved organic matter using ultrahigh resolution electrospray ionization Fourier-transform ion cyclotron resonance mass spectrometry. Geochimica et Cosmochimica Acta 73:4384--99

Langenheder S, Lindstrom ES, Tranvik LJ. 2005. Weak coupling between community composition and functioning of aquatic bacteria. Limnol. Oceanogr. 50:957--67

Langenheder S, Lindstrom ES, Tranvik LJ. 2006. Structure and function of bacterial communities emerging from different sources under identical conditions. Appl. Environ. Microbiol. 72:212--20

Lau WWY, Armbrust EV. 2006. Detection of glycolate oxidase gene glcD diversity among cultured and environmental marine bacteria. Environ. Microbiol. 8:1688--702

Lee C, Wakeham S, Arnosti C. 2004. Particulate organic matter in the ocean: the composition conundrum. Ambio 33:559--68

Lennon JT. 2007. Diversity and metabolism of marine bacteria cultivated on dissolved DNA. Appl. Environ. Microbiol. 73:2799--805

Malmstrom RR, Cottrell MT, Elifantz H, Kirchman DL. 2005. Biomass production and assimilation of dissolved organic matter by SAR11 bacteria in the Northwest Atlantic Ocean. Appl. Environ. Microbiol. 71:2979--86

Malmstrom RR, Kiene RP, Cottrell MT, Kirchman DL. 2004a. Contribution of SAR11 bacteria to dissolved dimethylsulfoniopropionate and amino acid uptake in the North Atlantic Ocean. Appl. Environ. Microbiol. 70:4129--35

Malmstrom RR, Kiene RP, Kirchman DL. 2004b. Identification and enumeration of bacteria assimilating dimethylsulfoniopropionate (DMSP) in the North Atlantic and Gulf of Mexico. Limnol. Oceanogr. 49:597--606

Marañón E, Cermeno P, Fernandez E, Rodriguez J, Zabala L. 2004. Significance and mechanisms of photosynthetic production of dissolved organic carbon in a coastal eutrophic ecosystem. Limnol. Oceanogr. 49:1652--66

McBride MJ, Xie G, Martens EC, Lapidus A, Henrissat B, et al. 2009. Novel features of the polysaccharide-digesting gliding bacterium Flavobacterium johnsoniae as revealed by genome sequence analysis. Appl. Environ. Microbiol. 75:6864--75 
McCarthy MD, Hedges JI, Benner R. 1998. Major bacterial contribution to marine dissolved organic nitrogen. Science 281:231--34

Moore LR, Post AF, Rocap G, Chisholm SW. 2002. Utilization of different nitrogen sources by the marine cyanobacteria Prochlorococcus and Synechococcus. Limnol. Oceanogr. 47:989-96

Mopper K, Stubbins AP, Ritchie JD, Bialk HM, Hatcher PG. 2007. Advanced instrumentation approaches for the characterization of marine dissolved organic matter: extraction techniques, mass spectrometry, and nuclear magnetic resonance spectroscopy. Chem. Rev. $107: 419--42$

Moran M, Buchan A, Gonzalez JM, Heidelberg JF, Whitman WB, et al. 2004. Genome sequence of Silicibacter pomeroyi reveals adaptations to the marine environment. Nature 432:910--13

Morris JJ, Kirkegaard R, Szul MJ, Johnson ZI, Zinser ER. 2008. Facilitation of robust growth of Prochlorococcus colonies and dilute liquid cultures by "Helper" heterotrophic bacteria. Appl. Environ. Microbiol. 74:4530--34

Morris RM, Nunn BL, Frazar C, Goodlett DR, Ting YS, Rocap G. 2010. Comparative metaproteomics reveals ocean-scale shifts in microbial nutrient utilization and energy transduction. ISME J. 4:673--85

Mou XZ, Hodson RE, Moran MA. 2007. Bacterioplankton assemblages transforming dissolved organic compounds in coastal seawater. Environ. Microbiol. 9:2025--37

Mou XZ, Sun SL, Edwards RA, Hodson RE, Moran MA. 2008. Bacterial carbon processing by generalist species in the coastal ocean. Nature 451:708--11

Nagata T. 2000. Production mechanisms of dissolved organic matter. In Microbial Ecology of the Oceans, ed. DL Kirchman, pp. 121--52. New York: Wiley-Liss

Nagata T. 2008. Organic matter--bacteria interactions in seawater. In Microbial Ecology of the Oceans, ed. DL Kirchman, pp. 207--42. Hoboken, NJ: Wiley

Nagata T, Kirchman DL. 1990. Filtration-induced release of dissolved free amino acids: application to cultures of marine protozoa. Mar. Ecol. Prog. Ser. 68:1--5

Nagata T, Kirchman DL. 1992. Release of macromolecular organic complexes by heterotrophic marine flagellates. Mar. Ecol. Prog. Ser. 83:233--40

Nagata T, Meon B, Kirchman DL. 2003. Microbial degradation of peptidoglycan in seawater. Limnol. Oceanogr. 48:745--54 
Ogawa H, Amagai Y, Koike I, Kaiser K, Benner R. 2001. Production of refractory dissolved organic matter by bacteria. Science 292:917--20

Ouverney CC, Fuhrman JA. 2000. Marine planktonic Archaea take up amino acids. Appl. Environ. Microbiol. 66:4829--33

Palenik B, Brahamsha B, Larimer FW, Land M, Hauser L, et al. 2003. The genome of a motile marine Synechococcus. Nature 424:1037--42

Palenik B, Ren QH, Dupont CL, Myers GS, Heidelberg JF, et al. 2006. Genome sequence of Synechococcus CC9311: insights into adaptation to a coastal environment. Proc. Natl. Acad. Sci. USA 103:13555--59

Pantoja S, Lee C. 1999. Peptide decomposition by extracellular hydrolysis in coastal seawater and salt marsh sediment. Mar. Chem. 63: 273-91

Pantoja S, Lee C, Marecek JF. 1997. Hydrolysis of peptides in seawater and sediment. Mar. Chem. 57: 25-40

Paul C, Barofsky A, Vidoudez C, Pohnert G. 2009. Diatom exudates influence metabolism and cell growth of cocultured diatom species. Mar. Ecol. Prog. Ser. 389:61--79

Penn K, Jenkins C, Nett M, Udwary DW, Gontang EA, et al. 2009. Genomic islands link secondary metabolism to functional adaptation in marine Actinobacteria. ISME J. 3:1193-203

Pinhassi J, Azam F, Hemphala J, Long RA, Martinez J, et al. 1999. Coupling between bacterioplankton species composition, population dynamics and organic matter degradation. Aquat. Microb. Ecol. 17:13--26

Poretsky RS, Hewson I, Sun SL, Allen AE, Zehr JP, Moran MA. 2009. Comparative day/night metatranscriptomic analysis of microbial communities in the North Pacific subtropical gyre. Environ. Microbiol. 11:1358--75

Poretsky RS, Sun S, Mou X, Moran MA. 2010. Transporter genes expressed by coastal bacterioplankton in response to dissolved organic carbon. Environ. Microbiol. 12:616--27

Porubsky WP, Velasquez LE, Joye SB. 2008. Nutrient-replete benthic microalgae as a source of dissolved organic carbon to coastal waters. Estuar. Coasts 31:860--76

Raes J, Bork P. 2008. Molecular eco-systems biology: towards an understanding of community function. Nat. Rev. Microbiol. 6:693--99 
Ram RJ, VerBerkmoes NC, Thelen MP, Tyson GW, Baker BJ, et al. 2005. Community proteomics of a natural microbial biofilm. Science 308:1915--20

Rink B, Seeberger S, Martens T, Duerselen CD, Simon M, Brinkhoff T. 2007. Effects of phytoplankton bloom in a coastal ecosystem on the composition of bacterial communities. Aquat. Microb. Ecol. 48:47--60

Rocap G, Larimer FW, Lamerdin J, Malfatti S, Chain P, et al. 2003. Genome divergence in two Prochlorococcus ecotypes reflects oceanic niche differentiation. Nature 424:1042--47

Rossello-Mora R, Lucio M, Pena A, Brito-Echeverria J, Lopez-Lopez A, et al. 2008. Metabolic evidence for biogeographic isolation of the extremophilic bacterium Salinibacter ruber. ISME J. 2:242--53

Rusch DB, Halpern AL, Sutton G, Heidelberg KB, Williamson S, et al. 2007. The Sorcerer II Global Ocean Sampling expedition: Northwest Atlantic through Eastern Tropical Pacific. PLoS Biol. 5:398--431

Schwalbach MS, Tripp HJ, Steindler L, Smith DP, Giovannoni SJ. 2010. The presence of the glycolysis operon in SAR11 genomes is positively correlated with ocean productivity. Environ. Microbiol. 12:490--500

See JH, Bronk DA, Lewitus AJ. 2006. Uptake of Spartina-derived humic nitrogen by estuarine phytoplankton in nonaxenic and axenic culture. Limnol. Oceanogr. 51:2290--99

Sinsabaugh RL, Findlay SEG. 2003. Dissolved organic matter: out of the black box into the mainstream. In Aquatic Ecosystems: Interactivity of Dissolved Organic Matter, ed. SEG Findlay, RL Sinsabaugh, pp. 479--98. San Diego, CA: Elsevier

Sleighter RL, Hatcher PG. 2008. Molecular characterization of dissolved organic matter (DOM) along a river to ocean transect of the lower Chesapeake Bay by ultrahigh resolution electrospray ionization Fourier transform ion cyclotron resonance mass spectrometry. Mar. Chem. 110:140--52

Sogin ML, Morrison HG, Huber JA, Mark Welch D, Huse SM, et al. 2006. Microbial diversity in the deep sea and the underexplored "rare biosphere." Proc. Natl. Acad. Sci. USA 103:12115--20

Sowell SM, Norbeck AD, Lipton MS, Nicora CD, Callister SJ, et al. 2008. Proteomic analysis of stationary phase in the marine bacterium "Candidatus Pelagibacter ubique." Appl. Environ. Microbiol. 74:4091--100 
Sowell SM, Wilhelm LJ, Norbeck AD, Lipton MS, Nicora CD, et al. 2009. Transport functions dominate the SAR11 metaproteome at low-nutrient extremes in the Sargasso Sea. ISME J. 3:93--105

Strom SL. 2008. Microbial ecology of ocean biogeochemistry: a community perspective. Science $320: 1043--45$

Teira E, Gasol JM, Aranguren-Gassis M, Fernandez A, Gonzalez J, et al. 2008. Linkages between bacterioplankton community composition, heterotrophic carbon cycling and environmental conditions in a highly dynamic coastal ecosystem. Environ. Microbiol. 10:906--17

Teira E, Pazo MJ, Serret P, Fernandez E. 2001. Dissolved organic carbon production by microbial populations in the Atlantic Ocean. Limnol. Oceanogr. 46:1370--77

Teira E, van Aken H, Veth C, Herndl GJ. 2006. Archaeal uptake of enantiomeric amino acids in the meso- and bathypelagic waters of the North Atlantic. Limnol. Oceanogr. 51:60--69

Todd JD, Curson ARJ, Nikolaidou-Katsaraidou N, Brearley CA, Watmough NJ, et al. 2010. Molecular dissection of bacterial acrylate catabolism---unexpected links with dimethylsulfoniopropionate catabolism and dimethyl sulfide production. Environ. Microbiol. $12: 327--43$

Treusch AH, Vergin KL, Finlay LA, Donatz MG, Burton RM, et al. 2009. Seasonality and vertical structure of microbial communities in an ocean gyre. ISME J. 3:1148--63

Tringe SG, von Mering C, Kobayashi A, Salamov AA, Chen K, et al. 2005. Comparative metagenomics of microbial communities. Science 308:554--57

Tripp HJ, Bench SR, Turk KA, Foster Ra, Desany BA, et al. 2010. Metabolic streamlining in an open-ocean nitrogen-fixing cyanobacterium. Nature 464:90--94

Tyson GW, Chapman J, Hugenholtz P, Allen EE, Ram RJ, et al. 2004. Community structure and metabolism through reconstruction of microbial genomes from the environment. Nature 428:37--43

Vallino JJ. 2010. Ecosystem biogeochemistry considered as a distributed metabolic network ordered by maximum entropy production. Philos. Trans. R. Soc. B 365:1417--27

van Oijen T, Veldhuis MJW, Gorbunov MY, Nishioka J, van Leeuwe MA, de Baar HJW. 2005. Enhanced carbohydrate production by Southern Ocean phytoplankton in response to in situ iron fertilization. Mar. Chem. 93:33--52 
Venter JC, Remington K, Heidelberg JF, Halpern AL, Rusch D, et al. 2004. Environmental genome shotgun sequencing of the Sargasso Sea. Science 304:66--74

Vila-Costa M, Simo R, Harada H, Gasol JM, Slezak D, Kiene RP. 2006. Dimethylsulfoniopropionate uptake by marine phytoplankton. Science 314:652--54

Walker CB, de la Torre JR, Klotz MG, Urakawa H, Pinel N, et al. 2010. Nitrosopumilus maritimus genome reveals unique mechanisms for nitrification and autotrophy in globally distributed marine crenarchaea. Proc. Natl. Acad. Sci. USA 107:8818--23

Webb EA, Ehrenreich IM, Brown SL, Valois FW, Waterbury JB. 2009. Phenotypic and genotypic characterization of multiple strains of the diazotrophic cyanobacterium, Crocosphaera watsonii, isolated from the open ocean. Environ. Microbiol. 11:338--48

Wetz MS, Wheeler PA. 2007. Release of dissolved organic matter by coastal diatoms. Limnol. Oceanogr. 52:798--807

Wichard T, Poulet SA, Boulesteix AL, Ledoux JB, Lebreton B, et al. 2008. Influence of diatoms on copepod reproduction. II. Uncorrelated effects of diatom-derived alpha, beta, gamma, delta-unsaturated aldehydes and polyunsaturated fatty acids on Calanus helgolandicus in the field. Prog. Oceanogr. 77:30--44

Worden AZ, Lee J-H, Mock T, Rouze P, Simmons MP, et al. 2009. Green evolution and dynamic adaptations revealed by genomes of the marine picoeukaryotes Micromonas. Science 324:268--72

Zinser ER, Lindell D, Johnson ZI, Futschik ME, Steglich C, et al. 2009. Choreography of the transcriptome, photophysiology, and cell cycle of a minimal photoautotroph, Prochlorococcus. PLoS ONE 4:e5135

Zubkov MV, Fuchs BM, Archer SD, Kiene RP, Amann R, Burkill PH. 2001. Linking the composition of bacterioplankton to rapid turnover of dissolved dimethylsulphoniopropionate in an algal bloom in the North Sea. Environ. Microbiol. 3:304--11 
Table 1 Dissolved organic matter production by monocultures, cocultures and environmental consortia

\begin{tabular}{|c|c|c|c|c|c|}
\hline & Organism name & DOM-type & $\begin{array}{l}\text { Experimental } \\
\text { conditions }\end{array}$ & Notes & Reference(s) \\
\hline \multirow{16}{*}{ 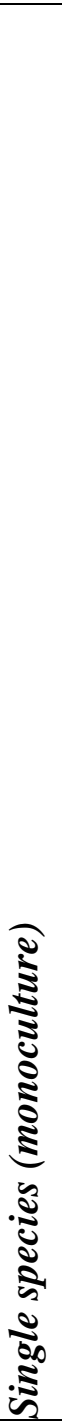 } & $\begin{array}{l}\text { Salinospora tropica, S. } \\
\text { arenicola } \\
\text { (Actinomycetes) }\end{array}$ & Secondary metabolites & Genome sequence & & Penn et al. 2009 \\
\hline & $\begin{array}{l}\text { Flavobacterium } \\
\text { johnsoniae } \\
\text { (Bacteroidetes) }\end{array}$ & Secondary metabolites & Genome sequence & Freshwater isolate & McBride et al. 2009 \\
\hline & $\begin{array}{l}\text { Polaribacter sp. } \\
\text { (Bacteroidetes) }\end{array}$ & Exopolysaccharides & Genome sequence & & Gonzalez et al. 2008 \\
\hline & $\begin{array}{l}\text { Salinibacter ruber } \\
\text { (Bacteroidetes) }\end{array}$ & Metabolites (ESI/FT-ICR MS) & Laboratory culture & $\begin{array}{l}28 \text { isolates showed unique profiles } \\
\text { associated with location of isolation }\end{array}$ & Rossello-Mora et al. 2008 \\
\hline & $\begin{array}{l}\text { Pirellula sp. } \\
\text { (planctomycete) }\end{array}$ & Polyketide antibiotics & Genome sequence & & Glockner et al. 2003 \\
\hline & $\begin{array}{l}\text { Pseudomonas } \\
\text { chlororaphis ( } \gamma \text { - } \\
\text { proteobacteria) }\end{array}$ & Metabolites (ESI/MS) & $\begin{array}{l}\text { Laboratory culture } \\
\text { with high C }\end{array}$ & $\begin{array}{l}\text { DOM composition shifted after 1--2 } \\
\text { days; relatively constant thereafter }\end{array}$ & Gruber et al. 2006 \\
\hline & $\begin{array}{l}\text { Synechococcus } \\
\text { PCC7002 } \\
\text { (photosynthetic } \\
\text { cyanobacterium) }\end{array}$ & Siderophores & $\begin{array}{l}\text { Laboratory culture } \\
\text { with Fe limitation }\end{array}$ & Structures provided & Ito \& Butler 2005 \\
\hline & $\begin{array}{l}\text { Synechococcus } \\
\text { WH8102 }\end{array}$ & Unknown & Genome sequence & $\begin{array}{l}\text { Efflux transporters; organic substrates } \\
\text { not specified }\end{array}$ & Palenik et al. 2003 \\
\hline & $\begin{array}{l}\text { Trichodesmium } \\
\text { erythraeum }\left(\mathrm{N}_{2} \text {-fixer }\right. \\
\text { cyanobacterium })\end{array}$ & Phosphonates & Laboratory culture & $10 \%$ of DOP; structure unknown & Dyhrman et al. 2009 \\
\hline & $\begin{array}{l}\text { Emiliana huxleyi } \\
\text { (coccolithophore) }\end{array}$ & Exopolysaccharides (NMR) & Laboratory culture & $\begin{array}{l}\text { After bacterial degradation, EPS are } \\
\text { similar to marine HMW DOM }\end{array}$ & Aluwihare \& Repeta 1999 \\
\hline & \multirow[t]{2}{*}{$\begin{array}{l}\text { Thalassiosira } \\
\text { pseudonana (diatom) }\end{array}$} & $\begin{array}{l}\text { Chitin, chitin-based } \\
\text { oligosaccharides, fatty acids }\end{array}$ & Genome sequence & & Armbrust et al. 2004 \\
\hline & & Metabolites (LC/TOF-MS) & Laboratory culture & Varied within and between growth stages & Barofsky et al. 2009 \\
\hline & T. weissflogii & Exopolysaccharides (NMR) & Laboratory culture & See E. huxleyi & Aluwihare \& Repeta 1999 \\
\hline & $\begin{array}{l}\text { Skeletonema marinoi } \\
\text { (diatom) }\end{array}$ & Metabolites (LC/TOF-MS) & Laboratory culture & $\begin{array}{l}\text { Varied within and between growth } \\
\text { stages; more peaks than T. pseudonana }\end{array}$ & Barofsky et al. 2009 \\
\hline & \multirow[t]{2}{*}{ Skeletonema costatum } & DFAA, DCAA & Laboratory culture & Exuded only after $\mathrm{N}$ depletion & Granum et al. 2002 \\
\hline & & Monosaccharides & Laboratory culture & $\sim 15 \%$ of DOC after $\mathrm{N}$ depletion & Granum et al. 2002 \\
\hline
\end{tabular}




\begin{tabular}{|c|c|c|c|c|c|}
\hline & & Polysaccharides & Laboratory culture & $\sim 33 \%$ of DOC after $\mathrm{N}$ depletion & Granum et al. 2002 \\
\hline \multirow{6}{*}{ 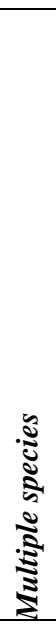 } & $\begin{array}{l}\text { P. chlororaphis + Uronema sp. } \\
\text { (scuticociliate) }\end{array}$ & Metabolites (ESI DOM) & Laboratory culture & $\begin{array}{l}\text { DOM composition similar to ciliate but } \\
\text { concentration fluctuates }\end{array}$ & Gruber et al. 2006 \\
\hline & $\begin{array}{l}\text { Enterobacter aerogenes }+ \\
\text { Bodo caudatus }\end{array}$ & Metabolites (ESI FT-ICR MS) & Laboratory culture & $\begin{array}{l}\text { Unique profiles observed in control and } \\
\text { grazing cultures }\end{array}$ & Kujawinski et al. 2004 \\
\hline & T. weissflogii + S. costatum & Metabolites (LC/TOF-MS) & Laboratory culture & $\begin{array}{l}\text { S. costatum enhances } T \text {. weissflogii } \\
\text { growth, but } T \text {. weissflogii has no impact } \\
\text { on } S \text {. costatum growth. However, } \\
\text { metabolite profiles of both change in } \\
\text { coculture. }\end{array}$ & Paul et al. 2009 \\
\hline & \multirow{3}{*}{$\begin{array}{l}\text { Thalassiosira rotula + various } \\
\text { bacteria (one isolate from } \\
\text { each of the Roseobacter, } \\
\text { Hyphomonas, and } \\
\text { Flexibacteriaceae groups) }\end{array}$} & DFAA, DCAA & Laboratory culture & $\begin{array}{l}\text { Degraded in presence of bacteria; } \\
\text { accumulated in phytoplankton-only } \\
\text { controls }\end{array}$ & Grossart \& Simon 2007 \\
\hline & & DFCHO, DCCHO & Laboratory culture & $\begin{array}{l}\text { Exuded in all cultures but unique } \\
\text { composition in presence of bacteria }\end{array}$ & Grossart \& Simon 2007 \\
\hline & & TEP, CSP & Laboratory culture & Only in presence of bacteria & Grossart \& Simon 2007 \\
\hline \multirow{5}{*}{ 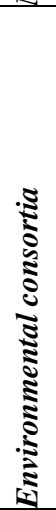 } & Mixed bacteria $(<0.7 \mu \mathrm{m})$ & Bulk DOC, monomers & $\begin{array}{l}\text { Incubations with } \\
\text { glucose }+\mathrm{NH}_{4}^{+} \text {or } \\
\text { glutamate }\end{array}$ & $\begin{array}{l}\text { Labile source utilized rapidly but } \\
\text { produced DOM with low reactivity } \\
(>1 \text { y) }\end{array}$ & Ogawa et al. 2001 \\
\hline & Benthic microalgae & Bulk DOC & $\begin{array}{l}\text { Field (intertidal); } \\
\text { Duplin River, } \\
\text { Georgia }\end{array}$ & $\begin{array}{l}\text { Production under nutrient replete } \\
\text { conditions }\end{array}$ & Porubsky et al. 2008 \\
\hline & \multirow{3}{*}{$\begin{array}{l}\text { Mixed consortium: } \\
\text { AU: Specify what the query } \\
\text { marks (used twice herein) } \\
\text { indicate?** my mistake] }\end{array}$} & d-alanine & $\begin{array}{l}\text { Incubations with } \\
\text { glucose }+\mathrm{NH}_{4}^{+}\end{array}$ & Released during exponential growth & Kawasaki \& Benner 2006 \\
\hline & & d-amino acids & $\begin{array}{l}\text { Incubations with } \\
\text { glucose }+\mathrm{NH}_{4}^{+}\end{array}$ & $\begin{array}{l}\text { Increase in incubations due to grazer } \\
\text { uptake of L-AA }\end{array}$ & Kawasaki \& Benner 2006 \\
\hline & & GlcN, GalN & $\begin{array}{c}\text { Incubations with } \\
\text { glucose }+\mathrm{NH}_{4}^{+}\end{array}$ & Not derived from bacterial peptidoglycan & Kawasaki \& Benner 2006 \\
\hline
\end{tabular}

Abbreviations: CSP, Coomassie-staining proteins; DFAA, dissolved free amino acids; DCAA, dissolved combined amino acids; DFCHO, dissolved free carbohydrates; DCCHO, dissolved combined carbohydrates; DOM. dissolved organic material; DOP, dissolved organic phosphorus; EPS, extracellular polymeric substances; GlcN, glucosamine; GalN, galactosamine (amino sugars); HMW, high molecular weight; L-AA, L-amino acids; LC/TOF-MS, liquid chromotography coupled to time-of-flight mass spectrometry; NMR, nuclear magnetic resonance; TEP, transparent exopolymers. 
Table 2 Consumption of specific compounds by monocultures and environmental consortia. Compounds classification should not be considered exclusive since some of the compounds shown here contain more than one heteroatom. Relative contributions of different clades within a field setting are discussed in text. Gene functional descriptions are copied directly from publications and are not the result of BLAST (Basic Local Alignment Search Tool) searches by the author. As a result, they may not provide the most current or specific functional classification

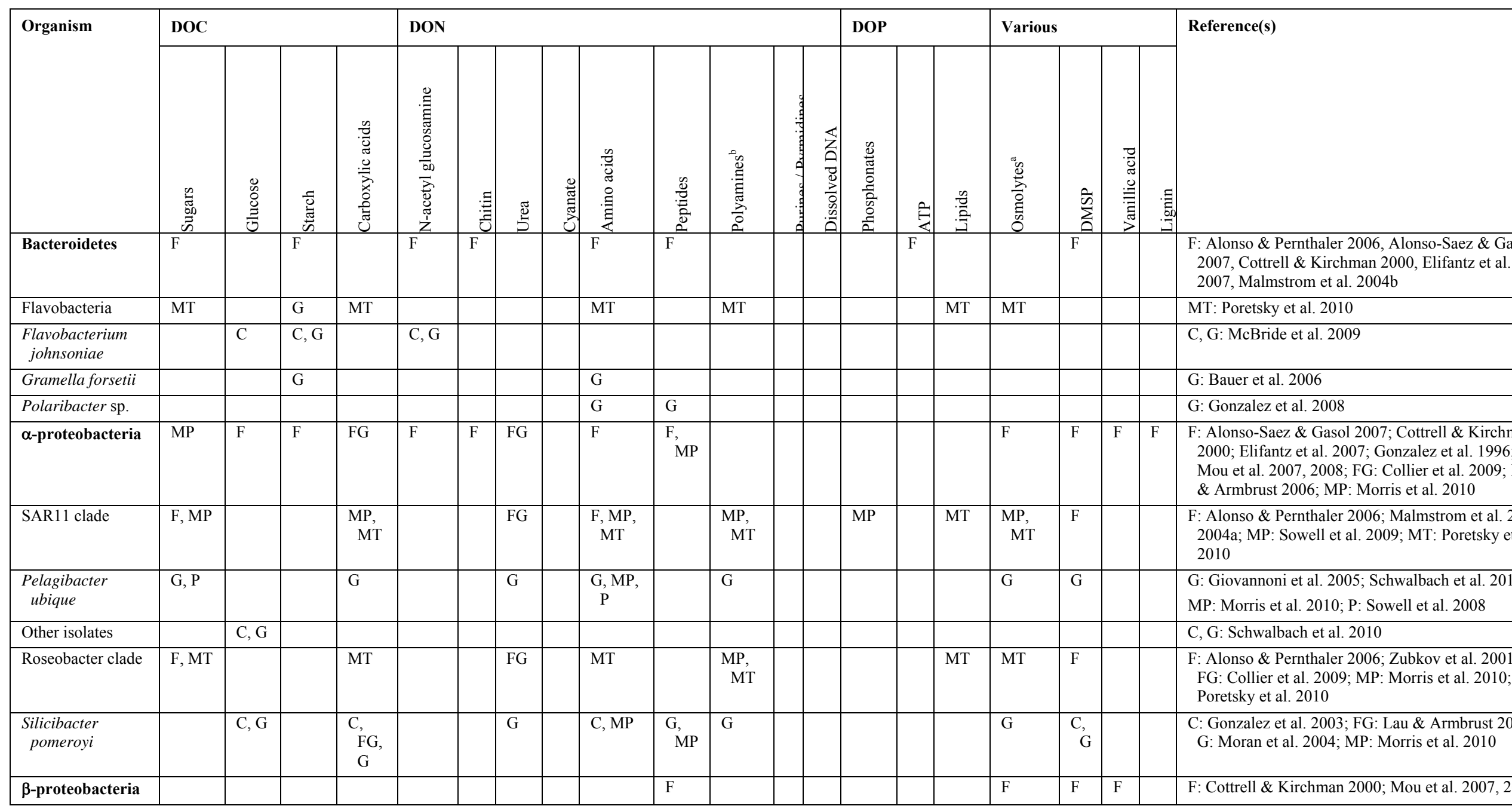




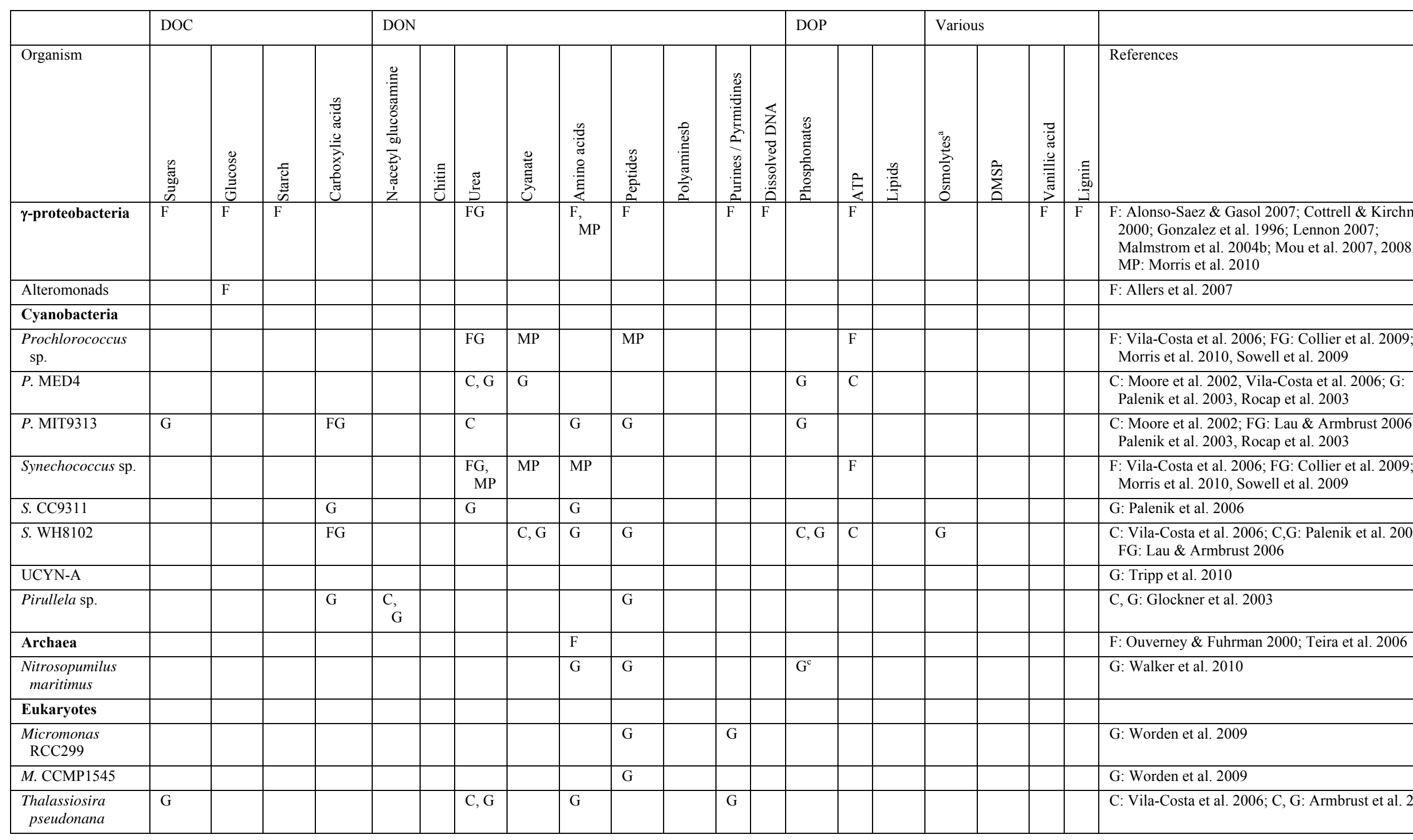

${ }^{a}$ e.g., glycine betaine

${ }^{\mathrm{b}}$ Polyamines, such as spermidine and putrescine 
${ }^{\mathrm{c}}$ Isolate could not grow on phosphonate compound in culture

Abbreviations: ATP, adenosine triphosphate; C, observed in culture or laboratory enrichment studies; DMSP, dimethylsulfopropionate; DOC, dissolved organic carbon; DON, disssolved organic nitrogen; DOP, dissolved organic phosphorus; F, observed in field studies by microscopy or bromodeoxyuridine incorporation; FT, functional-gene assay; G, genome sequence; MG, metagenome; MT, meta-transcriptome; MP, meta-proteome; P, proteome; UCYN-A, uncultured nitrogenfixing bacterium. 
Table 3 Review of consumption of complex dissolved organic matter from different sources

\begin{tabular}{|c|c|c|c|c|c|c|c|c|}
\hline Organism/Sample & $\begin{array}{l}\text { Surface- } \\
\text { derived } \\
\text { DOM }\end{array}$ & $\begin{array}{l}\text { Coastal } \\
\text { DOM }\end{array}$ & $\begin{array}{l}\text { Phytoplankton- } \\
\text { derived DOM }\end{array}$ & $\begin{array}{l}\text { Plant- } \\
\text { derived } \\
\text { DOM }\end{array}$ & $\begin{array}{l}\text { HMW } \\
\text { estuarine } \\
\text { DOM }\end{array}$ & $\begin{array}{l}\text { LMW } \\
\text { estuarine } \\
\text { DOM }\end{array}$ & $\begin{array}{l}\text { Humic } \\
\text { DOM }\end{array}$ & Reference(s) \\
\hline Bacteroidetes & & & $\mathrm{F}$ & & $\mathrm{F}$ & & & $\begin{array}{l}\text { F: Covert \& Moran 2001, } \\
\text { Rink et al. } 2007\end{array}$ \\
\hline Flavobacteria & & MT & & MT & & & & MT: Poretsky et al. 2010 \\
\hline$\alpha$-proteobacteria & & & & & $\mathrm{F}$ & & & F: Covert \& Moran 2001 \\
\hline SAR11 clade & & MT & MT & & & & & MT: Poretsky et al. 2010 \\
\hline Roseobacter clade & & MT & $\mathrm{F}, \mathrm{MT}$ & MT & & & & $\begin{array}{l}\text { F: Covert \& Moran 2001, } \\
\text { Rink et al. 2007; MT: } \\
\text { Poretsky et al. } 2010\end{array}$ \\
\hline Rhodobacteriaceae & & & $\mathrm{F}$ & & & & & F: Allers et al. 2007 \\
\hline$\beta$-proteobacteria & & & & & $\mathrm{F}$ & & & F: Covert \& Moran 2001 \\
\hline \&-proteobacteria & & & & & & $\mathrm{F}$ & & F: Covert \& Moran 2001 \\
\hline$\gamma$-proteobacteria & & MT & & & & $\mathrm{F}$ & & $\begin{array}{r}\text { F: Covert \& Moran 2001; } \\
\text { MT: Poretsky et al. } 2010\end{array}$ \\
\hline $\begin{array}{l}\text { Deepwater (200 } \\
\text { m) bacteria }\end{array}$ & $\mathrm{F}$ & & & & & & & F: Carlson et al. 2004 \\
\hline $\begin{array}{l}\text { Nonaxenic } \\
\text { phytoplankton }\end{array}$ & & & & & & & $\mathrm{C}$ & C: See et al. 2006 \\
\hline
\end{tabular}

Abbreviations: C, observed in culture or laboratory enrichment studies; DOC, dissolved organic carbon; DOM, disssolved organic matter; F, observed in field studies by microscopy or bromodeoxyuridine incorporation; HMW, high molecular weight; LMW, low molecular weight; MT, meta-transcriptome 


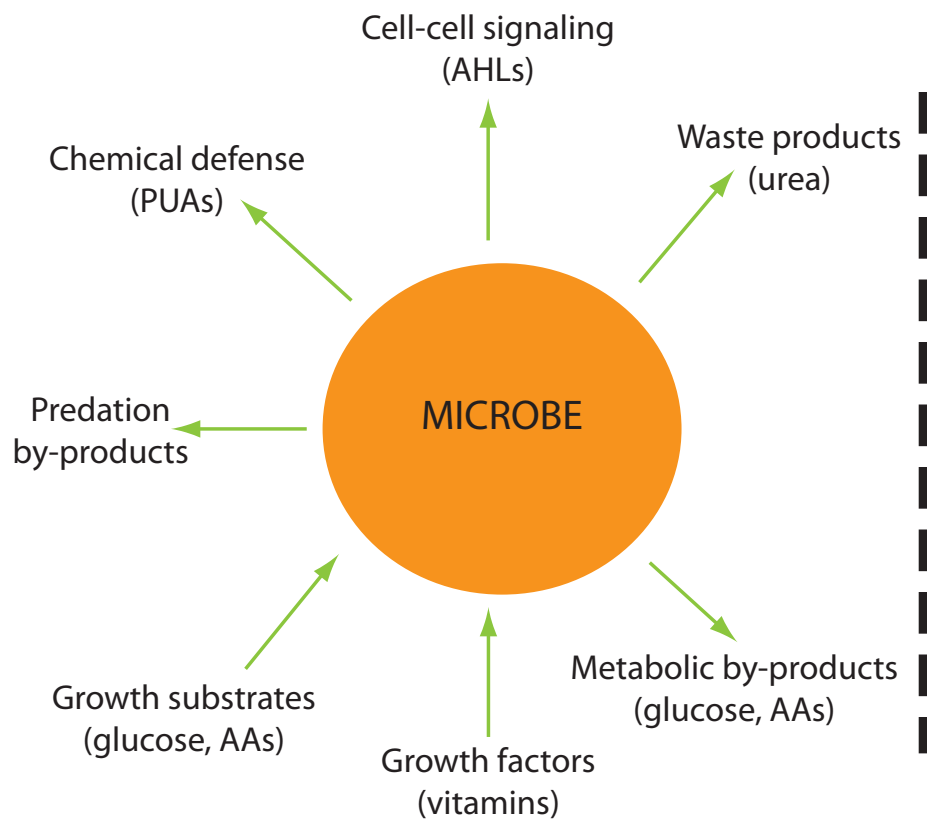

Bacteriodetes

(Cytophaga, Flavobacteria)

Roseobacter
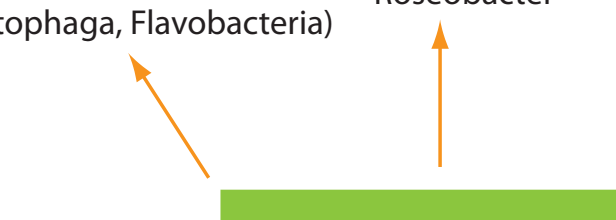

Cyanobacteria

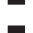

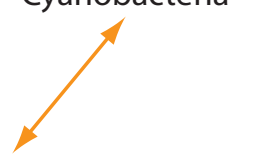

SAR11

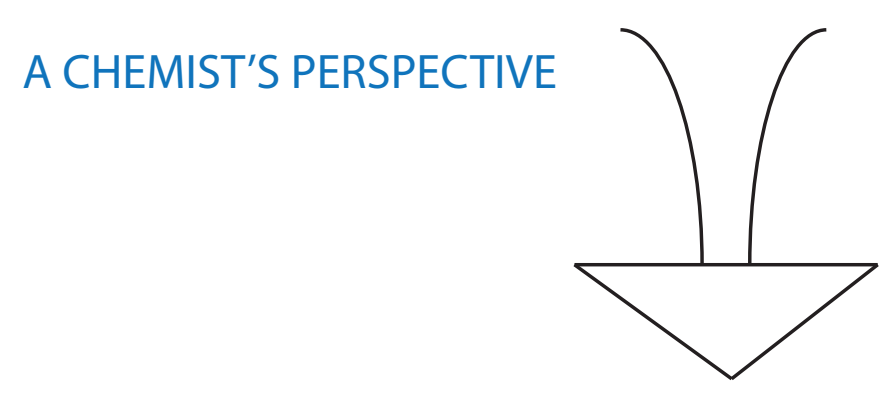

A BIOLOGIST'S PERSPECTIVE

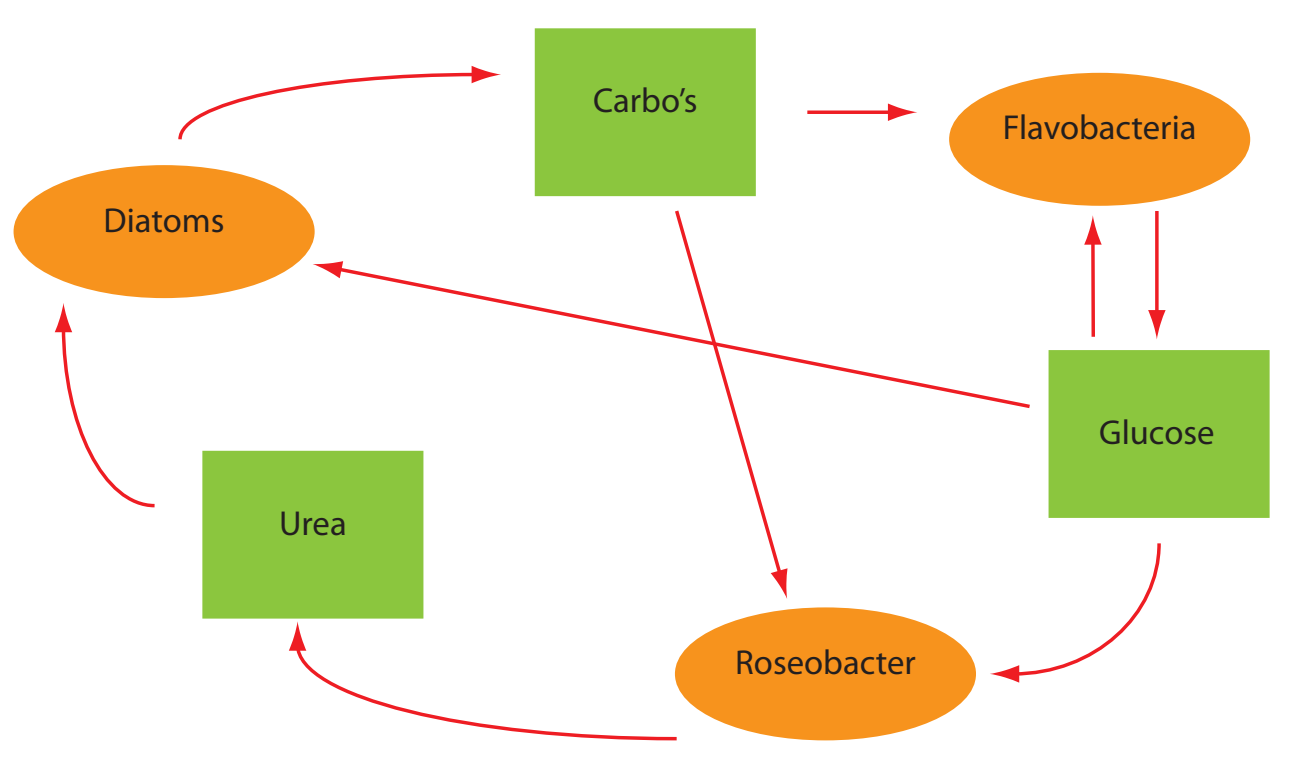

AN INTEGRATED PERSPECTIVE

Figure 1. The integration of chemical and biological perspectives on DOM-microbe interactions. Although important insights are gained from each field's perspective on DOM-microbe interactions, they are also limited by their lack of description in the other field. Through the integration of perspectives and datasets, we may find interesting connections that explain biogeochemical cycles. 


\section{Mass Spectrometry: Overview}

Inlet:

Make ions
Mass Spectrometer:

Measure $\mathrm{m} / \mathrm{z}$ of ions

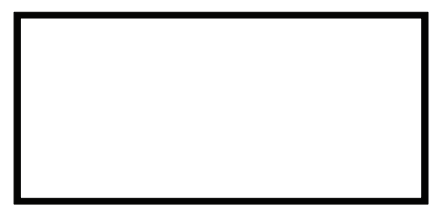

Electron impact (EI): Neutral compounds converted to ions by collision with electron beam

Chemicalionization (Cl):Neutral compounds converted to ions by collision with non-reactive gas $\left(\mathrm{CH}_{4}\right)$

Electrosprayionization (ESI): Ionic compounds introduced directly to MS

Matrix-assisted laser desorption ionization (MALDI): Neutral compounds on surface ablated and ionized by laser
Quadrupole: lons separated by mass filter within electric field on four parallel rods; $\mathrm{m} / \mathrm{z}$ measured by current induction on detection plate ( $\pm 1-2 \mathrm{amu})$

Ion-trap: lons separated by ejection from voltage trap; $\mathrm{m} / \mathrm{z}$ measured by current induction on detection plate $( \pm 1 \mathrm{amu})$

Time - of -flight (ToF): lons separated by passage through long flight tube; $\mathrm{m} / \mathrm{z}$ measured by impact on detection plate $( \pm 0.1 \mathrm{amu})$

Fourier - transform ion cyclotron resonance (FT ICR): lons separated by interaction with magnetic field; $\mathrm{m} / \mathrm{z}$ measured by current induction in two opposing detection plates ( $\pm 0.0001 \mathrm{amu})$

Figure 2. Overview of ionization methods and mass spectrometer options. The mass precision is given for an ion at $m / z 400$, in general terms. 

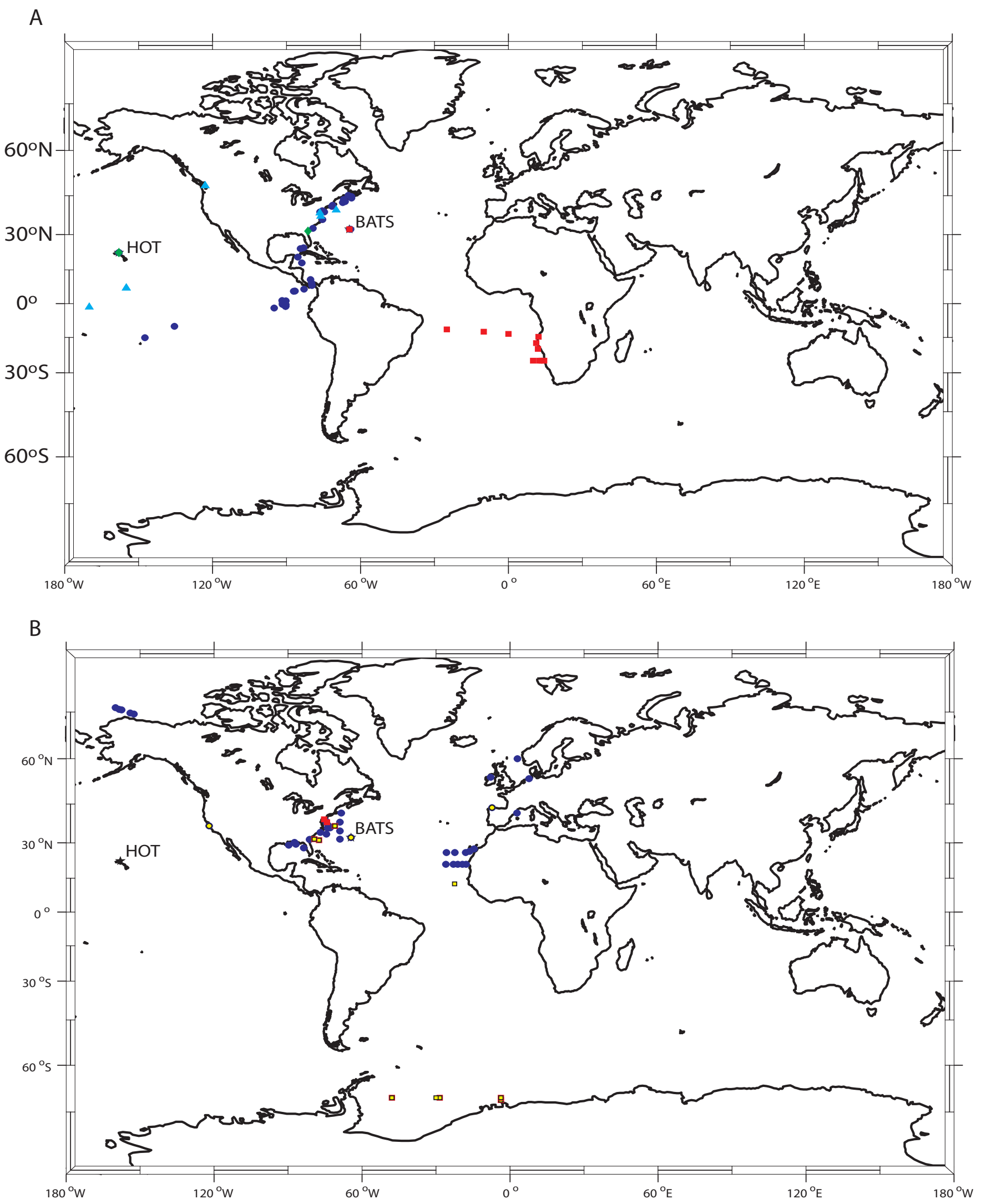

Figure 3. Maps of sampling locations for genomics-based analyses (A) and DOM or DOM-utilizationbased analyses (B). In the top figure, samples for metagenomics (circles), metaproteomics (squares), metatranscriptomics (diamonds) and functional-gene assays (triangles) are shown. In the bottom figure, samples for DOM-utilization-assays (circles) and DOM characterization (by ESI FT-ICR MS; squares) are shown. Yellow symbols indicate deep (>200 m) samples. In both, stars highlight the locations of the HOT and BATS stations. 
Figure 4.

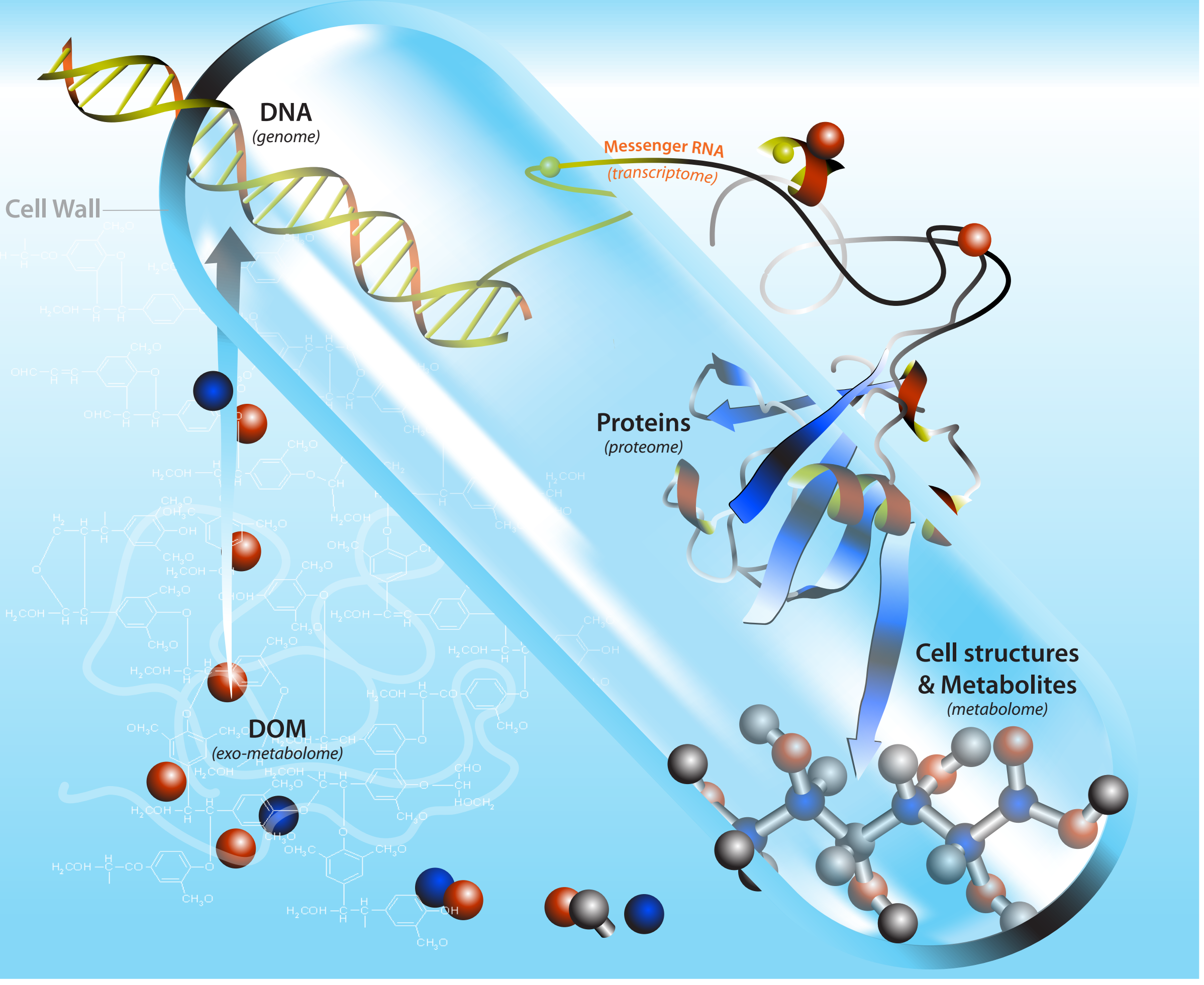

